\title{
Batch enrichment of anammox bacteria and study of the underlying microbial community dynamics
}

\author{
Romain Connan ${ }^{a}$, Patrick Dabert ${ }^{a}$, Hassan Khalil ${ }^{a}$, Gilbert Bridoux ${ }^{b}$, Fabrice Béline ${ }^{a}$, Albert Magrí ${ }^{a, *}$ \\ a IRSTEA, UR OPAALE, 17 Avenue de Cucillé-CS 64427, F-35044 Rennes, France \\ ${ }^{\mathrm{b}}$ SAUR, Atlantis, 1, Avenue Eugène Freyssinet, F-78280, Guyancourt, France
}

\section{H I G H L I G H T S}

- Effect of nitrite supply during batch enrichment of anammox sludge was investigated.

- Anammox activity was only developed when starting at low nitrite concentration.

- Final abundance of the hzo gene and anammox activity were positively correlated.

- Inoculum and enrichment conditions determined final microbial community structure.

- Enrichment conditions prompted selection of anammox species belonging to Ca. Brocadia.

\section{A R T I C L E I N F O}

\section{Article history:}

Received 27 January 2016

Received in revised form 30 March 2016

Accepted 31 March 2016

Available online 7 April 2016

\section{Keywords:}

Anaerobic ammonium oxidation

Biomass enrichment

Nitrite

Real-time quantitative polymerase chain

reaction

Next-generation sequencing

\begin{abstract}
A B S T R A C T
The anaerobic ammonium oxidation (anammox) consists on the biological conversion of ammonium $\left(\mathrm{NH}_{4}^{+}\right)$into dinitrogen gas under absence of oxygen. Nitrite $\left(\mathrm{NO}_{2}^{-}\right)$is a substrate of the anammox reaction, but also an inhibitor at high concentrations. This study investigates the effect of nitrite on the microbial community during the batch enrichment of anammox sludge. Six inoculums collected from different environments were enriched after a conditioning pretreatment and under controlled conditions during 4 months. Concerning the mineral medium used, two different nitrite supply strategies were applied; i.e., (i) initially low concentration at $25 \mathrm{mg} \mathrm{NO}_{2}^{-}-\mathrm{N} / \mathrm{L}$ and progressive increase to $150 \mathrm{mg} \mathrm{NO}_{2}^{-}-\mathrm{N} / \mathrm{L}$, and (ii) constant high concentration at $150 \mathrm{mg} \mathrm{NO}--\mathrm{N} / \mathrm{L}$. All tested inoculums developed anammox activity but only when the enrichment was started at low nitrite concentration. In such case, the specific ammonium conversion rates finally obtained ranged from $21 \pm 1$ to $118 \pm 1 \mathrm{mg} \mathrm{NH}_{4}^{+}-\mathrm{N} / \mathrm{g}$ VS/d (VS, volatile solids). Abundance of the functional gene encoding for the enzyme hydrazine oxidoreductase ( $h z o$ ) was assessed using the real-time quantitative polymerase chain reaction (q-PCR) showing positive correlation with the anammox activity finally reported. In addition, high-throughput DNA sequencing helped to elucidate the underlying microbial community dynamics. The raw inoculum source, the conditioning pretreatment, and the cultivation conditions applied were jointly determinants of the final microbial community structure of the enrichments despite a clear convergence at the end of the experimental period. On the other hand, the cultivation conditions alone determined the selection of anammox species belonging to the genus Candidatus Brocadia.
\end{abstract}

(ㄷ) 2016 Elsevier B.V. All rights reserved.

\section{Introduction}

The anaerobic ammonium oxidation (anammox) consists on the biological conversion of ammonium $\left(\mathrm{NH}_{4}^{+}\right)$into dinitrogen gas $\left(\mathrm{N}_{2}\right)$

\footnotetext{
* Corresponding author at: Institut national de Recherche en Sciences et Technologies pour l'Environnement et l'Agriculture (IRSTEA), 17 Avenue de Cucillé, CS 64427, F-35044 Rennes, France. Tel.: +33 223482121; fax: +33 223482115.

E-mail addresses: romain.connan@irstea.fr (R. Connan), patrick.dabert@irstea.fr (P. Dabert), khalil.hass.48@gmail.com (H. Khalil), gbridoux@saur.fr (G. Bridoux) fabrice.beline@irstea.fr (F. Béline), albert.magri@irstea.fr, albert.magri@gmail.com (A. Magrí).
}

under absence of oxygen. This is a chemolithoautotrophic microbial process where nitrite $\left(\mathrm{NO}_{2}^{-}\right)$acts as the electron acceptor. The anammox reaction also involves the production of a minor fraction of nitrate $\left(\mathrm{NO}_{3}^{-}\right)$. According to Strous et al. [1], the corresponding molar ratios for $\mathrm{NH}_{4}^{+}$consumption, $\mathrm{NO}_{2}^{-}$consumption, $\mathrm{N}_{2}$ production, and $\mathrm{NO}_{3}^{-}$production are 1.00:1.32:1.02:0.26, respectively. Metagenomic studies also suggest that nitric oxide (NO) and hydrazine $\left(\mathrm{N}_{2} \mathrm{H}_{4}\right)$ are intermediates in the anammox reaction [2]. The anammox process was discovered in the early 1990s in a denitrifying fluidized bed reactor [3] and the interest in this bioprocess has ever since been rising in fundamental and 
applied research fields, such as marine ecology and environmental biotechnology [4,5].

So far, six "Candidatus" anammox bacterial genera have been enriched [6,7] from wastewater treatment facilities and freshwater environments (Brocadia, Kuenenia, Jettenia, Anammoxoglobus and Anammoxomicrobium), as well as from marine environments (Scalindua). All these genera make a monophyletic branch within the phylum Planctomycetes. In physiological terms, they feature a specific cytoplasmatic membrane-bound organelle known as anammoxosome, which is the locus of the anammox catabolism. They are also characterized by a low growth rate, with doubling times of $2.1-11$ days (at $\sim 30^{\circ} \mathrm{C}$ ) equivalent to a maximum specific growth rate of $0.065-0.334 \mathrm{~d}^{-1}[1,8]$. Because of this slow biomass development, and the specialized metabolism, anammox bacteria may be difficult to culture. Yet, phylotypes related to the anammox genera have increasingly been observed by molecular means in diverse environments, such as activated sludge from wastewater treatment plants (WWTP) [9,10], marine sediments [11,12], freshwater environments [13], and terrestrial ecosystems [14].

Anammox bacteria have not been isolated in pure culture yet, thus pointing to the fact that they may coexist with other microbial species, even in bioreactors fed exclusively with mineral substrates $[8,15,16]$. The most frequent enrichment strategies have been based on different types of continuously operated bioreactors [17]; e.g., sequencing batch reactor (SBR), rotating biological contactor, up-flow biofilm reactor, or membrane bioreactor $[1,18$ 20]. Alternatively, enrichments have also been developed in batch cultures [9,21-23]. Many studies have shown that successful cultivation of anammox bacteria from conventional sludge takes long time; i.e., generally from 4 months to 1 year [24]. Such time will be influenced by factors like (i) the ecological characteristics of the seeding sludge including initial concentration and relative abundance of anammox bacteria [24], (ii) effective biomass retention inside the reactor [25], and (iii) the environmental conditions applied: temperature, $\mathrm{pH}$, and concentration of $\mathrm{NH}_{4}^{+}, \mathrm{NO}_{2}^{-}$, dissolved oxygen (DO), organic carbon, sulphide and other inhibitors like metals and antibiotics [26-28].

Monitoring the anammox activity usually involves the chemical analysis of relevant nitrogen $(\mathrm{N})$ compounds (i.e., $\mathrm{NH}_{4}^{+}, \mathrm{NO}_{2}^{-}$, and $\mathrm{NO}_{3}^{-}$) in the liquid phase. However, this strategy might be unsuccessful during the initial stages of the enrichment process, when the number of anammox cells is too low and their activity can still not be detected macroscopically. The use of culture-independent molecular methods has been proposed as a suitable method in such cases and various protocols for the DNA amplification by polymerase chain reaction (PCR) of target genes have been described in the literature, as summarized by Li et al. [12]. Anammox specific primers have been developed for amplifying ribosomal genes (16S rRNA) or functional genes such as that encoding for the enzyme hydrazine oxidoreductase (hzo) that dehydrogenates hydrazine to $\mathrm{N}_{2}$. These primers have been used to assess the abundance of anammox bacteria genes within environmental samples by real-time quantitative polymerase chain reaction (qPCR), and to analyze the microbial community diversity by molecular typing and sequencing methods [9,29-32]. Emerging nextgeneration sequencing (NGS) have also been applied for providing an in-depth characterization of the microbial biodiversity in anammox systems [33-36]. Yet, not so much information is available in the literature concerning the microbial community structure and dynamics during enrichment of the anammox biomass as determined by quantitative and qualitative culture-independent molecular methods.

Autotrophic nitrogen removal (ANR) applications based on anammox are promising for N-removal from municipal side-/mainstreams, industrial and agricultural wastewaters [37-40], particularly after anaerobic digestion once biodegradable organic carbon is depleted. However, anammox enriched sludge is not always available, and biomass enrichment can become the critical point for the start-up of the process. An appropriate selection of the environmental conditions applied is decisive for a successful enrichment. In this regard, $\mathrm{NO}_{2}^{-}$is a substrate of the anammox reaction but may also become an inhibitor at high concentrations. Such inhibition has been reported as highly case-specific; i.e., concentrations as low as 5 and $30 \mathrm{mg} \mathrm{NO}_{2}^{-}-\mathrm{N} / \mathrm{L}$ were found as inhibitory in some studies $[41,42]$ whereas much higher inhibitory boundaries of $210-274 \mathrm{mg} \mathrm{NO}_{2}^{-}-\mathrm{N} / \mathrm{L}$ were determined in other cases [43-45]. Concerning this variability, Kimura et al. [44] suggested that differences in $\mathrm{NO}_{2}^{-}$concentration tolerance may be caused by the cultivation conditions used. The aim of this study is to investigate the presence of anammox populations in different inoculum sources and to assess the feasibility of enrichment in batch under two different strategies concerning $\mathrm{NO}_{2}^{-}$supply. Thus, final concentrations of $150 \mathrm{mg} \mathrm{NO}_{2}^{-}-\mathrm{N} / \mathrm{L}$ were targeted in the mineral medium used as feeding solution but testing two different supply strategies (i.e., initially low vs. high concentration) in order to evaluate the effect of the $\mathrm{NO}_{2}^{-}$concentration when starting anammox batch enrichments. Use of molecular techniques will help to detect anammox bacteria and to establish correlations between macroscopically observed process parameters and the underlying microbial community dynamics. Microbial monitoring will be conducted using q-PCR and 16S rRNA gene targeted NGS.

\section{Materials and methods}

\subsection{Inoculum sources}

Six different biomass sources collected in conventional Nremoval facilities were considered as inoculum (I) for batch enrichment; i.e., (I1) activated sludge collected in a municipal WWTP that combine the use of a Modified Ludzack-Ettinger (MLE) bioreactor unit and a membrane filtration loop (Betton, Brittany, France), (I2) mixture of activated and settled sludge collected in a pig slurry treatment plant with intermittent aeration and gravity settling (Meslin, Brittany, France), (I3) activated sludge collected in a pig slurry treatment plant with MLE configuration (Calldetenes, Catalonia, Spain), (I4) settled sludge -sediments- collected in a receiving lagoon treating municipal wastewater (Amanlis, Brittany, France), (I5) settled sludge -sediments- collected in polishing lagoons treating municipal wastewater (Amanlis, Brittany, France), and (I6) settled sludge collected in an intermittently aerated lagoon treating pig slurry (Almacelles, Catalonia, Spain). The volatile solids (VS) content of the samples was $0.44 \%, 1.82 \%, 0.62 \%$, $0.82 \%, 0.48 \%$, and $1.92 \%$ of the wet weight, respectively; whereas, the corresponding VS/TS ratio (TS, total solids) was $0.52,0.64$, $0.54,0.09,0.09$, and 0.59 , respectively. In order to favor biodegradation of available organic carbon before incubation for anammox biomass enrichment, a conditioning pretreatment based on promoting denitrification was carried out at room temperature during the first days after sampling by adding a $\mathrm{NO}_{3}^{-}$source such as $\mathrm{KNO}_{3}$ in pulses of $722 \mathrm{mg} / \mathrm{L}(100 \mathrm{mg} \mathrm{N} / \mathrm{L})$ and controlling the $\mathrm{pH}$ within the range $7.0-8.0(\mathrm{HCl} 2 \mathrm{M})$. Batch enrichment was started once denitrification declined (after 2-4 weeks).

\subsection{Mineral medium}

The synthetic nutritive solution was prepared using tap water according to a modification of the mineral medium described by Magrí et al. [45]; i.e., $\mathrm{NH}_{4} \mathrm{Cl}$ (variable: $95-573 \mathrm{mg} / \mathrm{L}$ ), $\mathrm{NaNO}_{2}$ (variable: $123-739 \mathrm{mg} / \mathrm{L}), \mathrm{KNO}_{3}(361 \mathrm{mg} / \mathrm{L}), \mathrm{KHCO}_{3}(1000 \mathrm{mg} / \mathrm{L})$, $\mathrm{FeSO}_{4} \cdot 7 \mathrm{H}_{2} \mathrm{O}(9 \mathrm{mg} / \mathrm{L})$, EDTA $(5 \mathrm{mg} / \mathrm{L}), \mathrm{MgSO}_{4} \cdot 7 \mathrm{H}_{2} \mathrm{O}(240 \mathrm{mg} / \mathrm{L})$, 
$\mathrm{CaCl}_{2} \cdot 2 \mathrm{H}_{2} \mathrm{O}(143 \mathrm{mg} / \mathrm{L})$, and trace element solution $0.3 \mathrm{~mL} / \mathrm{L}$. The trace element solution contained $\mathrm{ZnSO}_{4} \cdot 7 \mathrm{H}_{2} \mathrm{O} \quad(1247 \mathrm{mg} / \mathrm{L})$, $\mathrm{MnSO}_{4} \cdot \mathrm{H}_{2} \mathrm{O}(1119 \mathrm{mg} / \mathrm{L}), \mathrm{CuSO}_{4} \cdot 5 \mathrm{H}_{2} \mathrm{O}(44 \mathrm{mg} / \mathrm{L}), \mathrm{Al}_{2}\left(\mathrm{SO}_{4}\right)_{3} \cdot 14 \mathrm{H}_{2} \mathrm{O}$ $(201.5 \mathrm{mg} / \mathrm{L}), \mathrm{Na}_{2} \mathrm{MoO}_{4} \cdot 2 \mathrm{H}_{2} \mathrm{O}(129 \mathrm{mg} / \mathrm{L}), \mathrm{CoCl}_{2} \cdot 6 \mathrm{H}_{2} \mathrm{O}(30 \mathrm{mg} / \mathrm{L})$, $\mathrm{KCl}(100 \mathrm{mg} / \mathrm{L})$, and EDTA $(975 \mathrm{mg} / \mathrm{L})$. Once dissolved the mineral salts, the DO was purged by bubbling with $\mathrm{N}_{2}(<0.2 \mathrm{mg} / \mathrm{L})$ and the $\mathrm{pH}$ was adjusted to $7.0(\mathrm{HCl} 2 \mathrm{M})$. The chemical $\mathrm{KNO}_{3}$ was added aiming to strengthen the anoxic conditions and to prevent potential sulphate reduction to sulphide (which could inhibit the anammox reaction) in case of total $\mathrm{NO}_{2}^{-}$consumption during the enrichment. Unfortunately, any phosphorus source was added to the nutritive solution throughout the enrichment due to a mistake, discovered later, in the labeling of the corresponding chemical $\left(\mathrm{K}_{2} \mathrm{O}(27 \mathrm{mg} / \mathrm{L})\right.$ was supplied instead of $\left.\mathrm{KH}_{2} \mathrm{PO}_{4}\right)$. Thus, it seems that the phosphorus released by the decaying biomass was enough to avoid limitation in the availability of this nutrient.

\subsection{Enrichment procedure}

Twelve glass bottles (total volume: $575 \mathrm{~mL}$; working volume: $500 \mathrm{~mL}$ ) containing inoculum and mineral medium were flushed with $\mathrm{N}_{2}$, sealed with a rubber stopper plus an aluminium cap, and placed in an incubator shaker (KS4000i control, IKA, Germany) at $150 \mathrm{rpm}, 35^{\circ} \mathrm{C}$, and in dark conditions. Initial VS content within the bottles was adjusted to $3 \mathrm{~g} / \mathrm{L}$. Biomass settling was allowed once per week (for $1 \mathrm{~h}$ ). Each bottle was then opened and the supernatant was manually withdrawn to avoid accumulation of inhibitory compounds while keeping the settled biomass inside of the bottles. Subsequently, the bottles were refilled with new nutritive mineral medium, closed, and flushed with $\mathrm{N}_{2}$. Two different strategies concerning $\mathrm{NO}_{2}^{-}$supply were applied (i.e., initially low vs. high concentration). Thus, mineral medium was prepared with low amount (25 mg $\left.\mathrm{NO}_{2}^{-}-\mathrm{N} / \mathrm{L}\right)$ or high amount $(150 \mathrm{mg}$ $\mathrm{NO}_{2}^{-}-\mathrm{N} / \mathrm{L}$ ) of $\mathrm{NO}_{2}^{-}$whereas $\mathrm{NH}_{4}^{+}$was added at a constant rate of $25 \mathrm{mg} \mathrm{NH}_{4}^{+}-\mathrm{N} / \mathrm{L}$. In those bottles running at low $\mathrm{NO}_{2}^{-}$concentration, once anammox activity was detected, a second weekly addition of $\mathrm{NO}_{2}^{-}$and $\mathrm{NH}_{4}^{+}\left(\mathrm{NO}_{2}^{-}-\mathrm{N} / \mathrm{NH}_{4}^{+}-\mathrm{N}=1.2\right)$ was carried out. Following this procedure, $\mathrm{NO}_{2}^{-}$content in the mineral medium was progressively increased from 25 to $150 \mathrm{mg} \mathrm{N} / \mathrm{L}$ at increments of $12.5 \mathrm{mg} \mathrm{N} / \mathrm{L}$. For the six bottles running at high $\mathrm{NO}_{2}^{-}$concentration, the $\mathrm{NO}_{2}^{-}$content was kept constant at $150 \mathrm{mg} \mathrm{N} / \mathrm{L}$ with only one feeding event per week throughout the experimental period. Concerning $\mathrm{NH}_{4}^{+}$content, it was proportionally increased at a ratio of $1.2 \mathrm{~g} \mathrm{NO}_{2}^{-}-\mathrm{N}$ per gram of $\mathrm{NH}_{4}^{+}-\mathrm{N}$ for those first six bottles initially running at low $\mathrm{NO}_{2}^{-}$concentration but it was kept constant at $25 \mathrm{mg} \mathrm{NH}+4$ $\mathrm{L}$ for the others. The $\mathrm{pH}$ within the bottles was controlled in the range from 7.0 to 8.0 using $\mathrm{HCl} 2 \mathrm{M}$. $\mathrm{N}_{2}$ flushing was used to displace air in the bottles headspace every time they were opened. The liquid volume exchanged when renewing the mineral medium was variable depending on the settling capability of the biomass, but usually between $60 \%$ and $80 \%$. This is a higher value than those generally considered in anammox SBRs [46-48]. The enrichment lasted 4 months. Liquid samples were taken before and after each new feeding event and filtered using $0.45 \mu \mathrm{m}$ polypropylene membrane filters prior to storage in the refrigerator. Biological samples were taken once per month, centrifuged at $10,000 \mathrm{~g}$ for $4 \mathrm{~min}$ and supernatants were discarded. Pellets were stored at $-20^{\circ} \mathrm{C}$.

\subsection{Final anammox activity test}

Final anammox activity was assessed using batch tests at the end of the enrichment period. According to the aforementioned conditions, after renewing the mineral medium, liquid samples were collected using syringes at regular time intervals for $\mathrm{N}$-compounds analysis. VS contents were also measured. The batch experiments were done in duplicate. Linear regression analyzes were used to describe N-conversion.

\subsection{Chemical analyzes}

$\mathrm{NH}_{4}^{+}, \mathrm{NO}_{2}^{-}$and $\mathrm{NO}_{3}^{-}$were measured by ion chromatography (850 Professional IC, Metrohm, Switzerland). TS were measured after sample drying to constant weight at $105{ }^{\circ} \mathrm{C}$ and VS were measured after further ignition in a muffle furnace at $550{ }^{\circ} \mathrm{C}$. The $\mathrm{pH}$ and DO were measured using portable meters pH 197i and Oxi 197 (WTW, Germany), respectively.

\subsection{Molecular analyzes}

\subsubsection{DNA extraction}

Total DNA was extracted from approximately $0.25 \mathrm{~g}$ of pellet with the PowerSoil ${ }^{\mathrm{TM}}$ DNA Isolation Kit (MoBio Laboratories Inc., USA), according to the instructions of the manufacturer. The concentration and purity of the extracted DNA were checked spectrophotometrically (ND-1000, NanoDrop Technologies, USA) and in TBE $1 \mathrm{X}-0.7 \%$ agarose gel. The extracted DNA was stored at $-20{ }^{\circ} \mathrm{C}$ until further analysis.

\subsubsection{Real-time $q-P C R$}

All real-time PCR amplifications were performed using the $\mathrm{iQ}^{\mathrm{TM}}$ SYBR $^{\circledR}$ Green supermix $(2 \times)$ (Bio-Rad Laboratories, USA) and the CFX96 real-time system equipped with the CFX Manager ${ }^{\mathrm{TM}}$ software v3.1 (Bio-Rad Laboratories), according to the instructions of the manufacturer. Quantification of total bacteria used universal eubacterial forward 1055F (5'-ATGGCTGTCGTCAGCT-3') and reverse 1392R (5'-ACGGGCGGTGTGTAC-3') primers to amplify the hypervariable V3-V5 region from the 16S rRNA gene, as previously reported by Ferris et al. [49]. Concerning anammox bacteria, the gene encoding specific enzyme HZO (hzo gene) was used as functional biomarker. The primer set used to selectively amplify anammox bacterial fragment was hzocl1F1 (5'-TGYAAGACYTGY CAYTGG-3') and hzocl1R2 (5'-ACTCCAGATRTGCTGACC- $3^{\prime}$ ) as described by Schmid et al. [50]. The PCR reactions were run in a $25 \mu \mathrm{L}$ volume containing $12.5 \mu \mathrm{L}$ of $\mathrm{iQ}^{\mathrm{TM}}$ SYBR $^{\circledR}$ Green supermix $(2 \times), 1.5$ or $0.625 \mu \mathrm{L}$ of each primer (eubacteria-16S rRNA or anammox-hzo, respectively; $10 \mu \mathrm{M}), 2 \mu \mathrm{L}$ of diluted DNA template, and 7.5 or $9.25 \mu \mathrm{L}$ of sterile water (eubacteria or anammox, respectively). To check against potential inhibition of the PCR amplification, reactions were done on DNA templates diluted 10- and 100folds and each reaction was carried out in triplicates. The amplification program applied for eubacteria was $95^{\circ} \mathrm{C}$ for $10 \mathrm{~min}$, followed by 45 cycles of denaturation at $95^{\circ} \mathrm{C}$ for $30 \mathrm{~s}$, annealing at $60{ }^{\circ} \mathrm{C}$ for $50 \mathrm{~s}$, and extension at $72{ }^{\circ} \mathrm{C}$ for $30 \mathrm{~s}$. In case of anammox bacteria, the program applied was $95^{\circ} \mathrm{C}$ for $2 \mathrm{~min}$, followed by 40 cycles of denaturation at $95^{\circ} \mathrm{C}$ for $30 \mathrm{~s}$, annealing at $51^{\circ} \mathrm{C}$ for $60 \mathrm{~s}$, and extension at $72{ }^{\circ} \mathrm{C}$ for $60 \mathrm{~s}$. The fluorescence intensity of the amplified DNA was measured after each extension step and a melting curve analysis was performed after completion of PCR. The microbial quantification was based on a mean slope value derived from standard curves obtained by q-PCR amplification of 10-fold successive dilutions of DNA fragments of the targeted genes [51], and which were purified using the Wizard ${ }^{\circledR}$ Plus SV Minipreps DNA Purification System (Promega, USA) according to the instructions of the manufacturer. The absolute copy number of DNA fragments per $\mu \mathrm{L}$ of standard solution was calculated from the concentration measured spectrophotometrically (ND-1000) and the molecular mass of the DNA fragment. The standard curves covered a range from $10^{2}$ to $10^{10}$ gene copies per $\mu \mathrm{L}$ of reaction. These series of standard dilutions were amplified along with the unknown samples during each q-PCR run, which allowed building the standard curve $\left(R^{2}>0.98\right)$ corresponding to each run. Results 
were expressed as gene copy number per $\mathrm{mL}$ of mixed liquor within the enrichment bottle.

\subsubsection{High-throughput DNA sequencing}

16S rRNA genes high-throughput DNA sequencing was performed at the NGS facility of the BIOMIC Team of IRSTEA (Antony, France) using Ion Torrent ${ }^{\mathrm{TM}}$ (Life Technologies, USA) technology and methods, according to the procedures described by Poirier et al. [52]. Briefly, the bacterial and archaeal hypervariable region V4-V5 of the 16S rRNA genes was amplified using the "universal" fusion-primers 515F (5'-GTGYCAGCMGCCGCGGTA-3') and 928R (5'-CCCCGYCAATTCMTTTRAGT-3') [53] modified to allow the tagging and sequencing of the amplified products. Amplification was performed in a $50 \mu \mathrm{L}$ reaction mixture containing $5 \mu \mathrm{L}$ of $P f x$ buffer $(10 \times), 1.5 \mu \mathrm{L}$ of dNTP mix (10 mM each), $1 \mu \mathrm{L}$ of $\mathrm{MgSO}_{4}(50 \mathrm{mM})$, $1.5 \mu \mathrm{L}$ of each primer $(10 \mu \mathrm{M}), 0.4 \mu \mathrm{L}$ of Platinum ${ }^{\circledR}$ Pfx DNA polymerase, $38.1 \mu \mathrm{L}$ of water and $1 \mu \mathrm{L}$ of extracted DNA (10-200 pg) (Pfx SuperMix protocol from Life Technologies). The mixture was held at $94{ }^{\circ} \mathrm{C}$ for $5 \mathrm{~min}$, followed by 30 cycles at $94{ }^{\circ} \mathrm{C}$ for $15 \mathrm{~s}$, $50{ }^{\circ} \mathrm{C}$ for $30 \mathrm{~s}$ and $68^{\circ} \mathrm{C}$ for $1 \mathrm{~min}$, and a final extension step at $68^{\circ} \mathrm{C}$ for $5 \mathrm{~min}$. PCR products were cleaned using the Agencourt ${ }^{\circledR}$ AMPure $^{\circledR}$ XP magnetic beads purification system (Beckman Coulter, USA) and quantified with a capillary electrophoresis bioanalyzer (2100 Electrophoresis Bioanalyzer, Agilent Technologies, USA). Purified libraries were diluted (in a first step at $500 \mathrm{pM}$ and later at $100 \mathrm{pM}$ ). Equal volumes of amplicons were combined in equimolar concentrations ( $100 \mathrm{pM})$ for sequencing using the Ion OneTouch $^{\mathrm{TM}} 2$ Instrument with the Ion PGM ${ }^{\mathrm{TM}}$ Template OT2 $400 \mathrm{Kit}$ and using a Ion Personal Genome Machine (PGM $\left.{ }^{\mathrm{TM}}\right)$ System with the Ion $316^{\mathrm{TM}}$ Chip Kit v2 and the Ion PGM ${ }^{\mathrm{TM}}$ Sequencing $400 \mathrm{Kit}$, according to the instructions of the manufacturer. Low quality and polyclonal sequence reads were filtered out by the PGM ${ }^{\mathrm{TM}}$ System software, and resulting data was exported as a FastQ file. 16S rRNA genes high-throughput DNA sequencing was performed directly on total DNA extracts to analyze global microbial community structure, and when anammox bacteria were not detected on PCR products obtained by specific amplification of the Planctomycetes phylum using the primers Pla46F and 1392R, as described in Bae et al. [9]. Sequences were analyzed using the Quantitative Insights into Microbial Ecology (QIIME v1.8.0) pipeline [54]. Sequences shorter than $200 \mathrm{bp}$, containing chimeras, and found as singletons were removed. Operational taxonomic units (OTUs) were subsequently defined using UPARSE implemented in USEARCH (v8.0.1623) [55] at a 97\% similarity level. MOTHUR (v1.25.0) [56] and SILVA (v119) [57] were used as the classifier tool and database for taxonomic association (with a minimum similarity threshold of $80 \%$ ), respectively.

\subsubsection{Statistical analyzes}

Statistical analysis to evaluate microbial community structure evolution was carried out through the non-metric multidimensional scaling (NMDS) method using the open-source software $\mathrm{R}$ (v3.2.3) [58] including functions from the vegan package (v2.3-2) [59]. Shannon-Weaver, Simpson, and Inverse Simpson diversity indices, as well as species richness and Pielou's evenness were calculated according to the procedures described in Oksanen et al. [59].

\section{Results and discussion}

\subsection{Performance of the anammox enrichment}

All tested inoculums developed positive anammox activity throughout the 4-month experimental period when the enrichment was started at low $\mathrm{NO}_{2}^{-}$concentration (Fig. 1A). However, biomass still maintained overall appearance of activated sludge and brownish color at the end of the enrichment. Three main enrichment phases were observed: (P1) endogenous heterotrophic denitrification was the dominant process and $\mathrm{NH}_{4}^{+}$may even slightly increase during incubation due to the hydrolysis of the remaining organic matter, (P2) occurrence of $\mathrm{NH}_{4}^{+}$consumption and subsequent speed up at increasing $\mathrm{NO}_{2}^{-}$concentration, and (P3) consolidation of $\mathrm{NH}_{4}^{+}$consumption at high $\mathrm{NO}_{2}^{-}$concentration with evidence of $\mathrm{NO}_{3}^{-}$production (while the $\mathrm{NO}_{2}^{-}-\mathrm{N} / \mathrm{NH}_{4}^{+}-\mathrm{N}$ reaction ratio became closer to the expected value of 1.32 [1]). Time for detecting $\mathrm{NH}_{4}^{+}$consumption under anaerobic conditions (beginning of P2) was variable (Table 1), ranging from 0 days in bottle seeded with I3 to 92 days in bottle seeded with I2 (time for anammox activity appearance was longer in those bottles seeded with the inoculums containing higher VS). According to this fact, and the progressive increase in the $\mathrm{NO}_{2}^{-}$supplied, concentrations of $150 \mathrm{mg} \mathrm{NO}_{2}^{-}-\mathrm{N} / \mathrm{L}$ at the beginning of a new batch were applied at the end of the experimental period in all cases except in bottle with $\mathrm{I} 2$, where the maximum concentration used was $50 \mathrm{mg} \mathrm{NO}--\mathrm{N} / \mathrm{L}$. On the other hand, no anammox activity was developed by any of the inoculums when enrichment was started at high $\mathrm{NO}_{2}^{-}$concentration (Fig. 1B), which evidences the importance of the feeding strategy adopted when targeting anammox bacteria enrichment and although $\mathrm{NO}_{2}^{-}$levels of $150 \mathrm{mg} \mathrm{N} / \mathrm{L}$ were not previously evaluated as inhibitory elsewhere [43-45].

Results of the final activity test did not evidence link between time of anammox activity appearance and measured $\mathrm{NH}_{4}^{+}$conversion rate (Table 1). Good linearity in the evolution of the $\mathrm{N}$-forms was observed during the activity test, which was indicative of no substrate inhibition $\left(R^{2}>0.98\right)$. Thus, specific activity was assessed within the range from 21 to $118 \mathrm{mg} \mathrm{NH}_{4}^{+}-\mathrm{N} / \mathrm{g} \mathrm{VS} / \mathrm{d}$ which is equivalent to total N-conversion rates of 59-297 mg N/g VS/d. These values are within the range of specific N-removal activities of 60 $1600 \mathrm{mg} \mathrm{N} / \mathrm{g} \mathrm{VSS} / \mathrm{d}$ ( $n=14$; VSS, volatile suspended solids) obtained for a variety of anammox sludges of diverse origins as reported by Van Hulle et al. [39].

The procedure followed in this study for the enrichment of anammox biomass consisted on the use of bottles as bioreactors (where substrates were supplied in pulses to the biomass). Eventual singularities of this method with respect to the use of the SBR technology are: long cycle ( $7 \mathrm{~d})$, long hydraulic residence time (>7 d), high volume exchange ratio (60-80\%), and exposure of the biomass to a wide range of substrate concentrations $(0-150 \mathrm{mg}$ $\mathrm{NO}_{2}^{-}-\mathrm{N} / \mathrm{L}$ ). These factors could influence on the evolution of the microbial community since they may have implications on the biomass retention within the reactor, the existence of famine periods during the enrichment, and the tolerance of high substrate concentrations by the biomass.

\subsection{Monitoring the enrichment of anammox bacteria by real-time $q$ - PCR}

The evolution of total and anammox bacteria was monitored by real-time q-PCR throughout the 4 months that lasted the experimental period. For a given batch enrichment, the bacterial $16 \mathrm{~S}$ rRNA gene was the most abundant and the least fluctuant (Fig. 2). Average values in the enrichments ranged from $2.5 \pm 0.2 \cdot 10^{6}$ to $1.0 \pm 0.2 \cdot 10^{9}$ copies $/ \mathrm{mL}$ depending on the inoculum source and the $\mathrm{NO}_{2}^{-}$supply strategy applied. Concerning the anammox hzo gene, it was quantified from the beginning of the experiment in all inoculums (Table 1), and a significant increase throughout the enrichment was evidenced in those cases where $\mathrm{NO}_{2}^{-}$was initially supplied at low concentration (Fig. 2). Conversely, that was not the case when $\mathrm{NO}_{2}^{-}$was initially supplied at high concentration. Thus, at day 0 , the hzo gene copy number in the enrichments started at low $\mathrm{NO}_{2}^{-}$concentration ranged from 


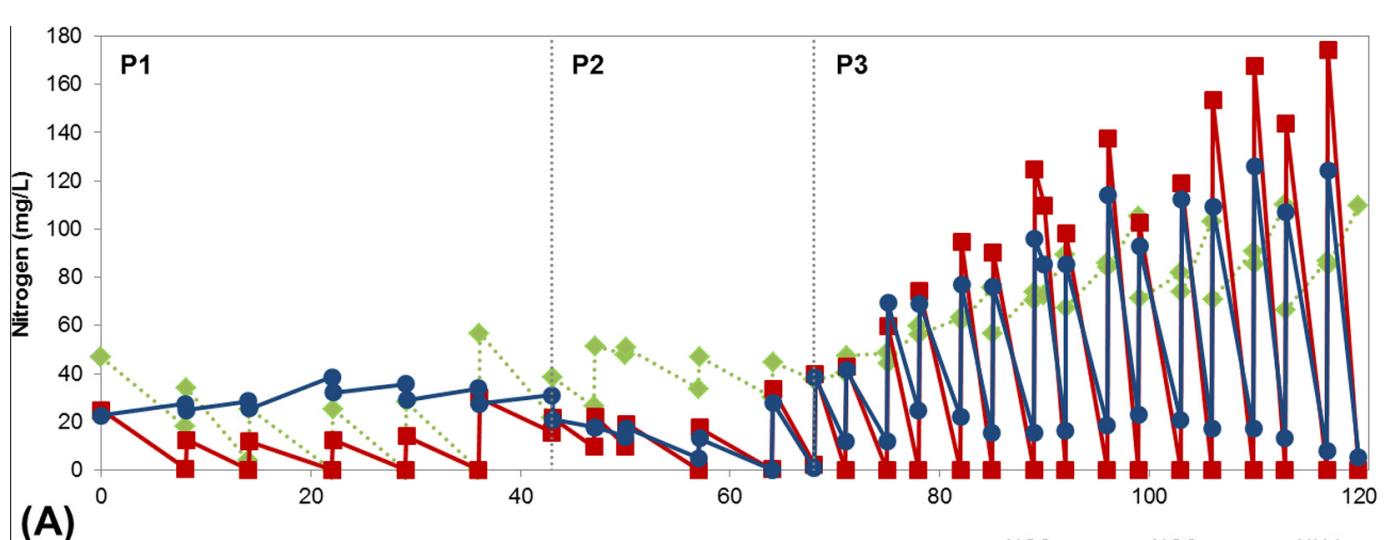

(A)
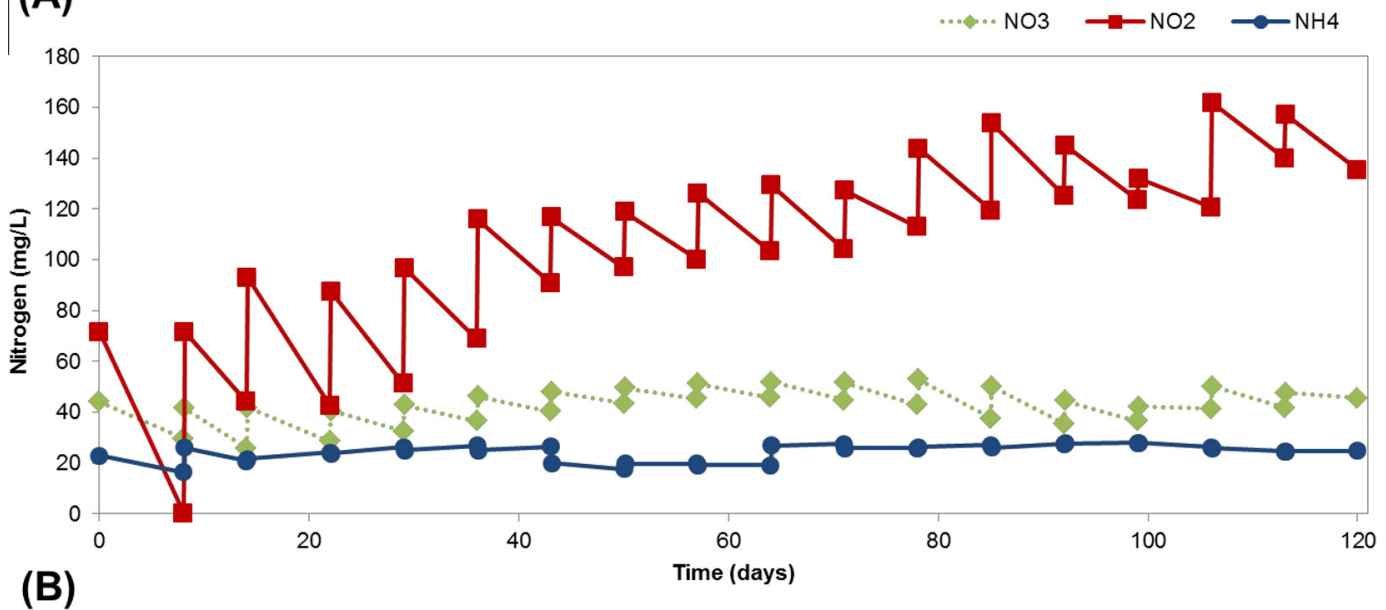

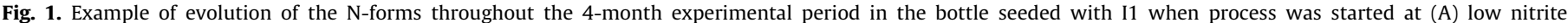
concentration and (B) high nitrite concentration.

Table 1

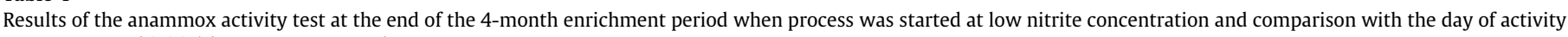
appearance and initial hzo gene copy number.

\begin{tabular}{|c|c|c|c|c|c|c|}
\hline Inoculum (source) & $\begin{array}{l}\text { Activity appearance } \\
\text { (days) }\end{array}$ & $\begin{array}{l}\mathrm{ACR}^{\mathrm{a}} \\
\left(\mathrm{mg} \mathrm{NH}_{4}^{+}-\mathrm{N} / \mathrm{L} / \mathrm{d}\right)\end{array}$ & $\begin{array}{l}\text { sACR } \\
\left(\mathrm{mg} \mathrm{NH}_{4}^{+}-\mathrm{N} / \mathrm{g} \mathrm{VS} / \mathrm{d}\right)\end{array}$ & $\begin{array}{l}\text { TNCR } \\
(\mathrm{mg} \mathrm{N} / \mathrm{L} / \mathrm{d})\end{array}$ & $\begin{array}{l}\mathrm{NO}_{2}^{-}-\mathrm{N} / \mathrm{NH}_{4}^{+}-\mathrm{N} \\
(-)\end{array}$ & 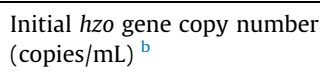 \\
\hline I1 (WWTP) & 43 & $222 \pm 2$ & $118 \pm 1$ & $560 \pm 11$ & $1.53 \pm 0.03$ & $6.3 \pm 1.4 \cdot 10^{4}$ \\
\hline I2 (PSTP) & 92 & $60 \pm 9$ & $42 \pm 6$ & $160 \pm 25$ & $1.67 \pm 0.01$ & $1.2 \pm 0.3 \cdot 10^{5}$ \\
\hline I3 (PSTP) & 0 & $164 \pm 6$ & $62 \pm 2$ & $373 \pm 17$ & $1.28 \pm 0.02$ & $5.2 \pm 0.8 \cdot 10^{4}$ \\
\hline I4 (LWWTP) & 57 & $78 \pm 1$ & $26 \pm 0$ & $208 \pm 8$ & $1.64 \pm 0.08$ & $3.3 \pm 0.3 \cdot 10^{4} *$ \\
\hline I5 (LWWTP) & 43 & $84 \pm 4$ & $21 \pm 1$ & $238 \pm 14$ & $1.83 \pm 0.02$ & $5.4 \pm 0.9 \cdot 10^{4} *$ \\
\hline I6 (LPSTP) & 77 & $162 \pm 12$ & $70 \pm 5$ & $370 \pm 37$ & $1.28 \pm 0.05$ & $1.1 \pm 0.2 \cdot 10^{5}$ \\
\hline
\end{tabular}

a ACR: ammonium conversion rate. SACR: specific ACR. TNCR: total nitrogen conversion rate. WWTP: wastewater treatment plant. PSTP: pig slurry treatment plant. LWWTP: lagoon WWTP. LPSTP: lagoon PSTP.

b Quantification of those samples labeled with $*$ was carried out at the detection limit.

$3.3 \pm 0.3 \cdot 10^{4}$ to $1.2 \pm 0.3 \cdot 10^{5}$ copies $/ \mathrm{mL}$, and after 4 months reached values from $1.1 \pm 0.1 \cdot 10^{6}$ to $1.5 \pm 0.1 \cdot 10^{7}$ copies $/ \mathrm{mL}$. At that time, it was also evidenced a positive correlation between the hzo gene copy number and the anammox activity (Fig. 3), similarly as previously reported by Tsushima et al. [29] using primers targeting the 16S rRNA gene of the anammox bacteria, and although there was no evident link between the hzo gene copy number in the inoculum at day 0 and the time of anammox activity appearance (Table 1). Lack of linkage between the initial hzo gene copy number and the time of anammox activity appearance suggests that other factors besides the initial anammox biomass concentration (measured as hzo gene copy number) determined the time when such activity became evident macroscopically. Among these factors, we might include competition for substrate, coexistence of the anammox bacteria with other microbial populations, and change of the growing anammox species (see Section 3.3). In this regard, mineralization of organic- $\mathrm{N}$ forms and denitrification could have masked an earlier detection of anammox activity. Furthermore, Tao et al. [24] pointed out dependence of the lag phase length not only on the initial biomass concentration but also on other ecological characteristics of the inoculum used and concluded that an evenly distributed community benefits the startup of the anammox process with shorter times and higher activities. Yet, differences exist between these findings and our study; i.e., we dealt with inoculums with much lower initial relative abundances of anammox bacteria and also we observed a change of the growing anammox species during the enrichment process (see Section 3.3). On the other hand, final hzo gene copy numbers were below $2.0 \pm 0.2 \cdot 10^{5}$ copies $/ \mathrm{mL}$ in all enrichments started at high $\mathrm{NO}_{2}^{-}$concentration. 

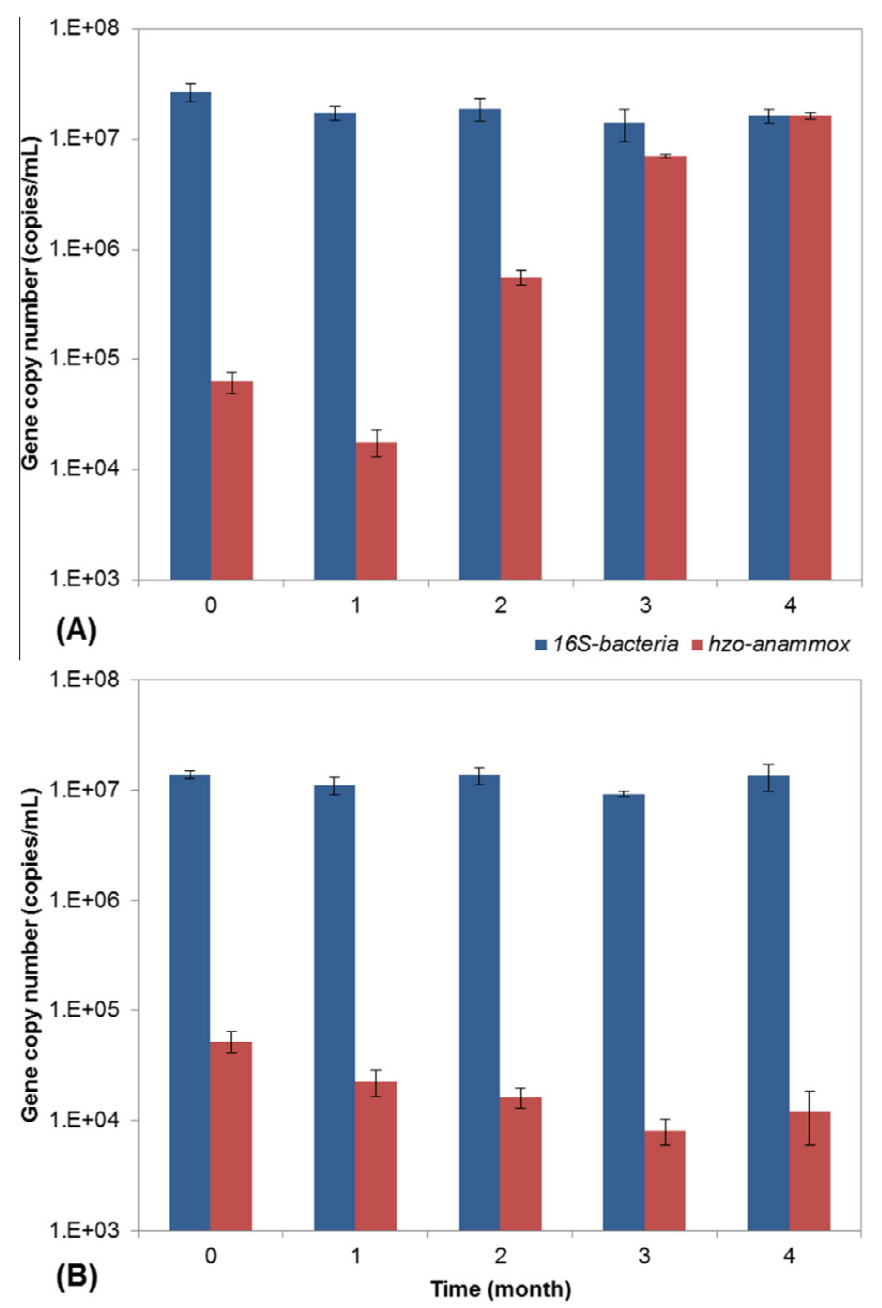

Fig. 2. Average copy number of bacterial $16 \mathrm{~S}$ rRNA and anammox hzo genes throughout the 4-month experimental period in the bottle seeded with I1 when process was started at (A) low nitrite concentration and (B) high nitrite concentration. Error bars represent \pm standard deviation.

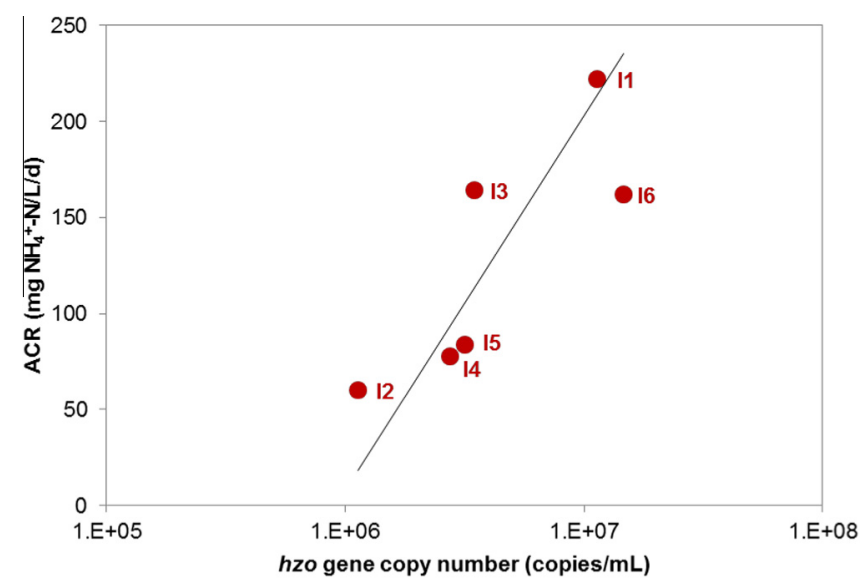

Fig. 3. Correlation between the ammonium conversion rate (ACR) and the hzo gene copy number at the end of the enrichment period ( 4 months) in the 6 batch cultures positive in anammox activity.

\subsection{Microbial community structure and dynamics during the enrichment}

The 16S rRNA high-throughput DNA sequencing was performed for all inoculums (I1-I6) at initial time (t0 $=0$ months) and final time ( $\mathrm{t} 4=4$ months) when the enrichment was started at low $\mathrm{NO}_{2}^{-}(\mathrm{LN})$ and high $\mathrm{NO}_{2}^{-}(\mathrm{HN})$ concentrations, and for $\mathrm{I} 3$ at all times (t0-t4) and $\mathrm{NO}_{2}^{-}$supply conditions (LN, HN). Reads obtained yielded between 1933 and 22475 high-quality sequences per sample that made up to 633 OTUs. A systematic random depletion was applied on the different datasets to equalize the number of sequences per sample; i.e., dataset for all inoculums including samples at initial and final time (18 samples) was adjusted to 11058 sequences per sample whereas dataset for I3 including samples at all times (9 samples) was adjusted to 1933 sequences per sample. The representativeness and identification of these OTUs was analyzed to better understand the process of anammox bacteria enrichment.

\subsubsection{Evolution of the microbial communities}

The diversity indices reported in Table 2; i.e., Shannon-Weaver, Simpson, and Inverse Simpson, globally show a systematic decrease of the microbial diversity throughout the enrichment (average index reductions for the enrichments started at low $\mathrm{NO}_{2}^{-}$concentration of $25.7 \pm 4.5 \%, 8.8 \pm 3.4 \%$, and $67.9 \pm 14.3 \%$, respectively). In addition, both the species richness and Pielou's evenness decreased in this period (average reductions for the cultures started at low $\mathrm{NO}_{2}^{-}$concentration of $30.2 \pm 7.6 \%$ and $20.5 \pm 4.7 \%$, respectively). These data may imply concomitant disappearance of some species and larger segregation between the low and highly represented taxons [60-61]. The impact seems to be more important when the enrichment was started at low $\mathrm{NO}_{2}^{-}$ concentration (Table 2). No relation was found between the initial microbial diversity and the effectiveness of the anammox enrichment in terms of both time required and final activity achieved.

Statistical analysis of the microbial community structure evolution was also performed through the NMDS method. For a given inoculum, the evolution of the microbial community was different depending on the $\mathrm{NO}_{2}^{-}$supply strategy applied during the enrichment. Relative differences in the composition of both microbiomes (enrichments started at low vs. high $\mathrm{NO}_{2}^{-}$concentration) over time were evidenced as it is shown for the bottle seeded with I3 in Fig. 4. Thus, although both microbiomes evolved similarly with a diminution in the diversity throughout the enrichment, divergence in the microbial community structure progressively increased and was maximal after 4 months of enrichment. Such divergence included the enrichment of anammox bacteria only under conditions of initially low $\mathrm{NO}_{2}^{-}$concentration. In addition, the NMDS analysis also revealed that, despite the significant relative differences in the composition of the microbial community concerning the inoculums used in this study, the enrichment conditions applied forced the convergence of such communities (Fig. 5). The most similar microbial community structures were observed for those inoculums coming from systems treating the same kind of wastewater; i.e., municipal (I1, I4, and I5) vs. pig slurry (I2, I3, and I6), at both initial and final time. The clear trend to converge independently of the inoculum source and the feeding strategy applied indicates the high selective pressure exerted by the experimental conditions here implemented.

\subsubsection{Description of the microbial community structures}

As aforementioned, the microbial community structure in the batch cultures evolved significantly throughout the enrichment. However, main phyla detected in inoculums such as Proteobacteria, Bacteroidetes, Firmicutes, Chloroflexi, Chlorobi, Acidobacteria, and Planctomycetes were also present at the end of the enrichment period (Fig. 6A and B; Tables 3 and 4). The phylum Proteobacteria, which is commonly found in wastewater treatment bioreactors, anaerobic digesters, and soils [62-64] was one of the most predominant at both initial time (relative abundances of $10.3-46.7 \%$ ) and final time (relative abundances of 23.9-55.5\%). For those 
Table 2

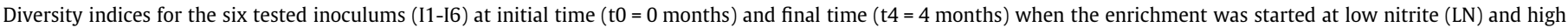
nitrite (HN) concentrations.

\begin{tabular}{|c|c|c|c|c|c|c|c|c|c|c|c|c|c|c|c|c|c|c|}
\hline \multirow[b]{2}{*}{ Indices } & \multicolumn{3}{|l|}{ I1 } & \multicolumn{3}{|l|}{$\mathrm{I} 2$} & \multicolumn{3}{|l|}{ I3 } & \multicolumn{3}{|l|}{ I4 } & \multicolumn{3}{|l|}{ I5 } & \multicolumn{3}{|l|}{ I6 } \\
\hline & to & $\mathrm{t} 4-\mathrm{LN}$ & $\mathrm{t} 4-\mathrm{HN}$ & to & $\mathrm{t} 4-\mathrm{LN}$ & t4-HN & to & t4-LN & t4-HN & to & t4-LN & $\mathrm{t} 4-\mathrm{HN}$ & to & $\mathrm{t} 4-\mathrm{LN}$ & $\mathrm{t} 4-\mathrm{HN}$ & to & $\mathrm{t} 4-\mathrm{LN}$ & $\mathrm{t} 4-\mathrm{HN}$ \\
\hline Shannon-Weaver & 4.02 & 2.99 & 3.15 & 4.22 & 2.92 & 3.44 & 4.24 & 3.52 & 4.03 & 3.91 & 2.83 & 3.21 & 4.40 & 3.10 & 3.44 & 4.07 & 3.10 & 3.43 \\
\hline Simpson & 0.96 & 0.89 & 0.87 & 0.97 & 0.88 & 0.94 & 0.96 & 0.93 & 0.97 & 0.95 & 0.83 & 0.92 & 0.98 & 0.85 & 0.93 & 0.97 & 0.90 & 0.93 \\
\hline Inverse Simpson & 28.0 & 8.77 & 7.55 & 36.3 & 8.19 & 15.7 & 23.2 & 14.3 & 30.2 & 20.6 & 5.88 & 12.1 & 40.8 & 6.87 & 14.5 & 31.4 & 9.88 & 14.2 \\
\hline Species richness & 245 & 165 & 187 & 255 & 163 & 209 & 358 & 235 & 287 & 262 & 177 & 199 & 303 & 206 & 221 & 239 & 207 & 226 \\
\hline Pielou's evenness & 0.73 & 0.59 & 0.60 & 0.76 & 0.57 & 0.64 & 0.72 & 0.64 & 0.71 & 0.70 & 0.55 & 0.61 & 0.77 & 0.58 & 0.64 & 0.74 & 0.58 & 0.63 \\
\hline
\end{tabular}

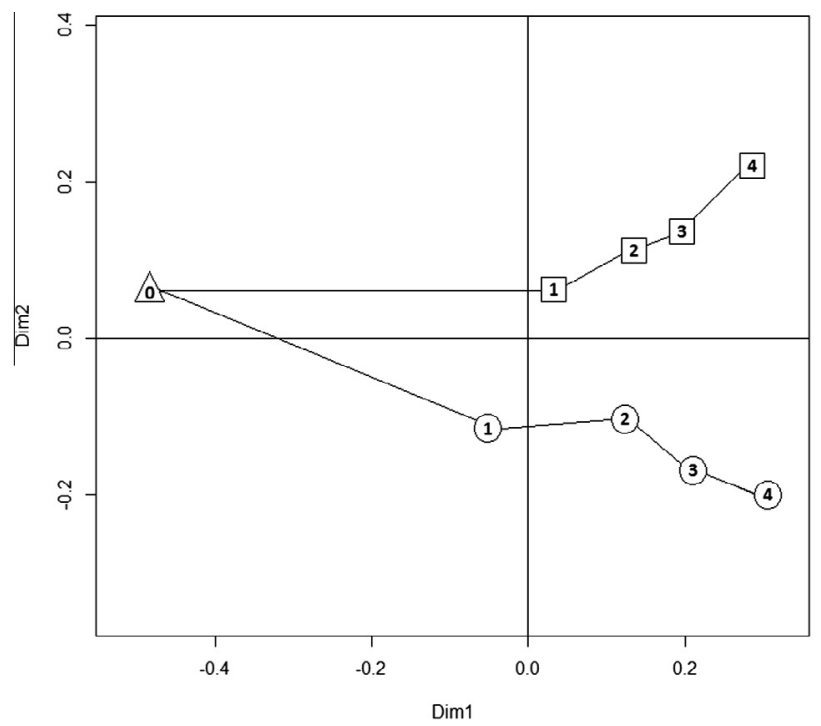

Fig. 4. Non-metric multidimensional scaling (NMDS) plot showing the evolution of the microbial community structure in both bottles seeded with I3 throughout the 4month experimental period. Circles correspond to the bottle started at low nitrite concentration whereas squares correspond to the bottle started at high nitrite concentration. Numbers inside circles and squares indicate the experimental time elapsed (in months).

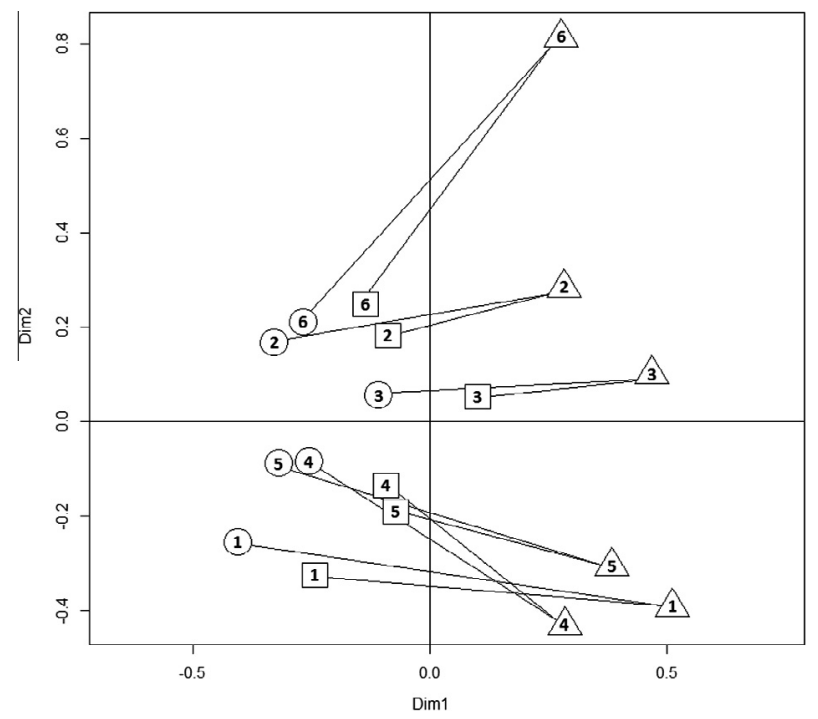

Fig. 5. Non-metric multidimensional scaling (NMDS) plot showing the evolution of the microbial community structure for all the inoculums tested (1-6) throughout the 4-month experimental period. Triangles correspond to initial time, circles correspond to final time for enrichments started at low nitrite concentration and squares correspond to final time for enrichments started at high nitrite concentration. enrichments started at low $\mathrm{NO}_{2}^{-}$concentration, the evolution of this phylum in terms of abundance was dependent on the inoculum source. Thus, the proportion of sequences belonging to this phylum followed an increase of $93.1 \pm 60.4 \%$ (in average) for those inoculums coming from pig slurry treatment plants (I2, I3, and I6) whereas followed a decrease of $19.6 \pm 16.0 \%$ (in average) for those inoculums coming from municipal WWTPs (I1, I4, and I5). On the other hand, for those enrichments started at high $\mathrm{NO}_{2}^{-}$concentration, the abundance of sequences belonging to this phylum increased at an average rate of $55.9 \pm 37.9 \%$ regardless the inoculum source. For I3 (Fig. 6B), the increased proportion of Proteobateria is essentially attributable to the evolution of genera belonging to the class Betaproteobacteria and family Rhodocyclaceae (OTUs 2 and 11) that contain several denitrifying species; e.g. Azoarcus. Bacteroidetes was another of the most represented phyla at initial time with proportions ranging from $6.1 \%$ to $30.9 \%$ in I 2 and I6, respectively. However, despite this initial high abundance, a systematic reduction was observed regardless the inoculum source and feeding strategy applied, with final relative abundances lower than $2.7 \%$. This is not surprising since the phylum Bacteroidetes contains both aerobic and anaerobic bacteria such as Sphingobacteriales and Bacteroides, respectively. In the case of I3 (Fig. 6B), the reduced proportion of Bacteroidetes is clearly linked to the disappearance of OTU 4 identified as a Sphingobacteriales Saprospiraceae. Conditions applied during the anoxic enrichment including the progressive abatement of residual organic compounds may be the cause of the depletion of this widespread phylum [62-64]. Concerning the phylum Firmicutes, relative abundance of sequences belonging to this phylum (0.7-18.6\%) was higher for those inoculums coming from pig slurry treatment facilities than for those others coming from municipal WWTPs; i.e., $12.7 \pm 6.2 \%$ vs. $1.0 \pm 0.2 \%$ in average, respectively. The corresponding quantitative evolution was slightly different depending on the $\mathrm{NO}_{2}^{-}$supply strategy. The coexistence of bacteria belonging to the phylum Chloroflexi is usually reported in anammox reactors being suggested that they can use decaying anammox bacterial cell materials [65]. Here, the evolution of this phylum (initial relative abundances of $2.1-12.9 \%$ ) was highly variable ranging from $67.7 \%$ decrease to $302.4 \%$ increase for I 2 enriched at initially low $\mathrm{NO}_{2}^{-}$concentration and $\mathrm{I} 6$ enriched at high $\mathrm{NO}_{2}^{-}$ concentration, respectively. Sequences corresponding to the phylum Chlorobi (initial relative abundances of $0.1-9.3 \%$ ) represented from $1.8 \%$ to $14.1 \%$ of total sequences at final time for I6 and I1, respectively. Concerning the phylum Acidobacteria, final relative abundance was lower than $4.0 \%$ in all cases. Planctomycetes, which contains all known anammox genera, did not become dominant in any of the enrichments that developed anammox activity (final relative abundances ranged from $0.6 \%$ to $7.7 \%$ for $\mathrm{I} 4$ and $\mathrm{I} 1$, respectively), which is in accordance with other microbial characterizations performed in anammox dedicated reactors [3435]. Within this group, the final relative abundance of sequences belonging to anammox species was between $31.7 \%$ and $75.3 \%$ for I2 and I1, respectively. For I3 (Fig. 6B), a significant enrichment of 

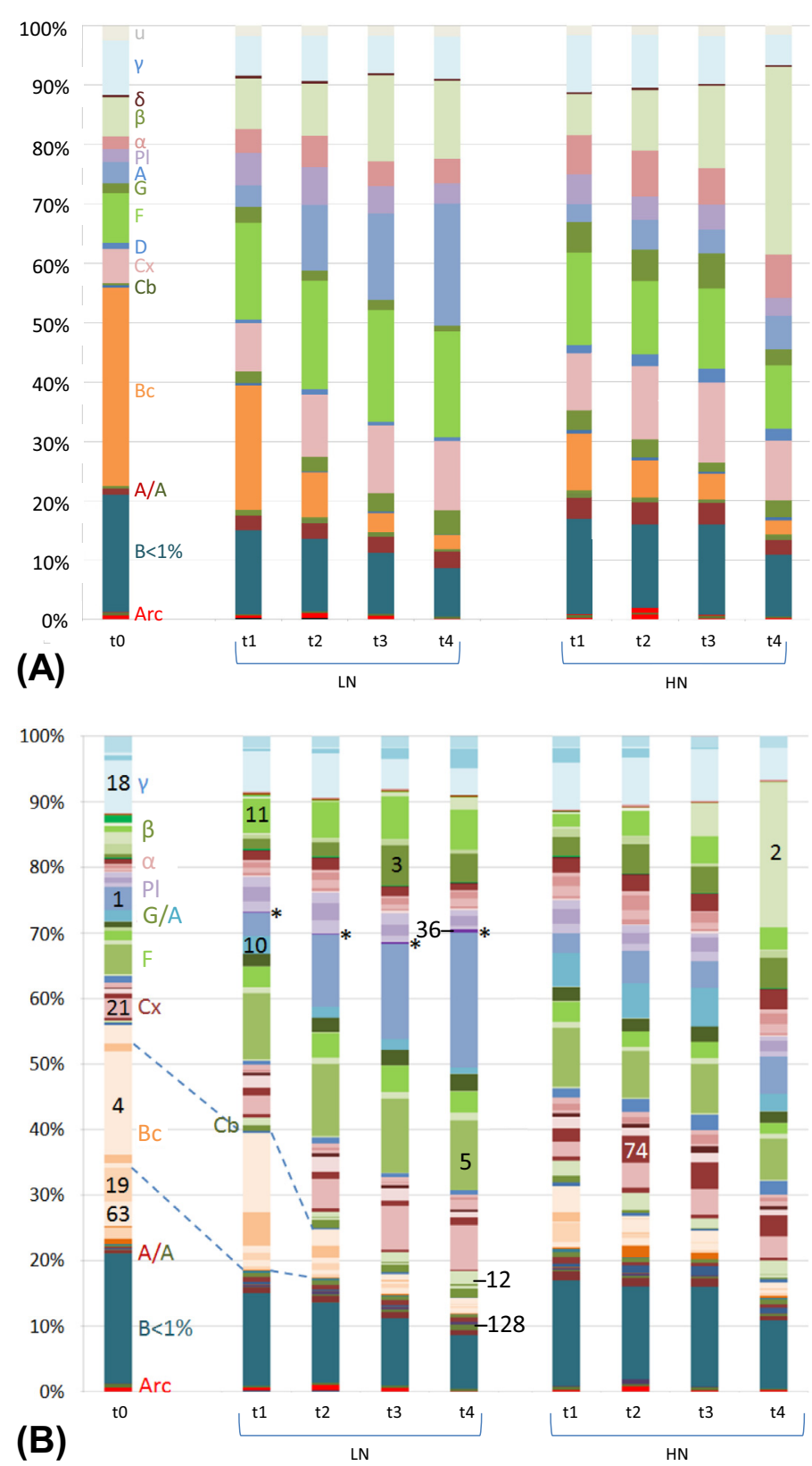

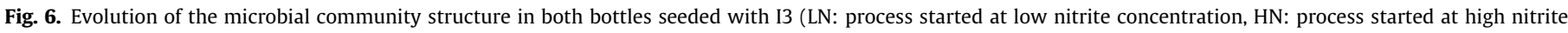

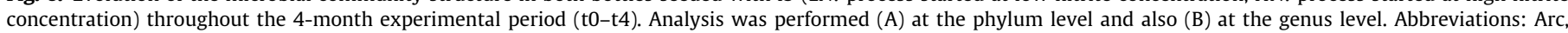

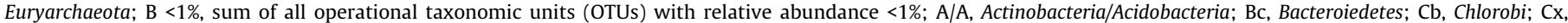

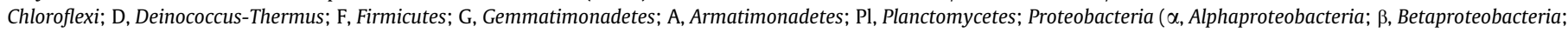
$\delta$, Deltaproteobacteria; $\gamma$, Gammaproteobacteria); u, unknown. $*$ is for Candidatus_Brocadia. Main OTUs are numbered and identified in Table 4.

OTU 1 belonging to phylum Armatimonadetes (formally called the candidate phylum OP10) was observed (similarly for other inoculums). Species belonging to the phylum Armatimonadetes have been detected in different natural environments such as the Obsidian Pool in Yellowstone National Park and freshwater lakes and rivers [66]. However, the reason of their enrichment in this study is not clear. OTU 36 was identified as Candidatus_Brocadia. In addition, 6 OTUs listed in Table 4 (from a total of 15) were identified as identical to sequences retrieved from anammox systems and 2 other OTUs were related to sequences retrieved from $\mathrm{N}$-removal systems. This fact suggests that the conditions applied to perform the enrichment also favored selection of other specific microbial groups that could either behave as partners or competitors of the anammox bacteria.

\subsubsection{Anammox genera}

Concerning the presence of anammox genera in the inoculums at initial time, Ca. Brocadia, Ca. Kuenenia, Ca. Anammoximicrobium and Ca. Jettenia were all detected (Fig. 7), although with an important disparity in terms of distribution and relative abundance. Thus, for instance, these four genera were detected together in I3 but not in the other inoculums. Otherwise, any of these genera were detected in I1. Ca. Jettenia was only detected when DNA samples were first amplified by means of selective PCR using 
Table 3

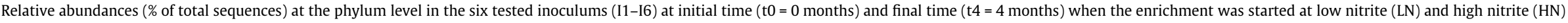
concentrations. "Others" includes all groups with relative abundance $<1 \%$.

\begin{tabular}{|c|c|c|c|c|c|c|c|c|c|c|c|c|c|c|c|c|c|c|}
\hline & \multicolumn{3}{|l|}{ I1 } & \multicolumn{3}{|l|}{$\mathrm{I} 2$} & \multicolumn{3}{|l|}{ I3 } & \multicolumn{3}{|l|}{$\mathrm{I} 4$} & \multicolumn{3}{|l|}{$\mathrm{I5}$} & \multicolumn{3}{|l|}{ I6 } \\
\hline & to & t4-LN & $\mathrm{t} 4-\mathrm{HN}$ & to & t4-LN & $\mathrm{t} 4-\mathrm{HN}$ & to & t4-LN & $\mathrm{t} 4-\mathrm{HN}$ & to & $\mathrm{t} 4-\mathrm{LN}$ & $\mathrm{t} 4-\mathrm{HN}$ & to & t4-LN & $\mathrm{t} 4-\mathrm{HN}$ & to & t4-LN & $\mathrm{t} 4-\mathrm{HN}$ \\
\hline Euryarchaeota & 0.09 & 0.04 & 0.07 & 0.18 & 0.20 & 0.25 & 0.59 & 0.15 & 0.43 & 0.14 & 0.05 & 0.13 & 0.42 & 0.30 & 0.38 & 1.90 & 0.58 & 0.95 \\
\hline Acidobacteria & 3.74 & 0.43 & 2.18 & 1.43 & 1.10 & 1.26 & 0.62 & 1.95 & 2.04 & 1.08 & 1.49 & 1.63 & 1.74 & 2.32 & 0.94 & 0.08 & 2.00 & 0.77 \\
\hline Actinobacteria & 5.29 & 1.01 & 4.00 & 5.47 & 0.32 & 3.04 & 0.86 & 1.65 & 2.60 & 0.30 & 0.55 & 0.75 & 0.49 & 1.12 & 1.29 & 0.04 & 0.82 & 1.22 \\
\hline Armatimonadetes & 6.33 & 24.43 & 15.59 & 4.72 & 26.41 & 9.98 & 3.18 & 20.35 & 4.79 & 2.61 & 38.50 & 14.48 & 2.66 & 35.48 & 9.61 & 5.37 & 21.45 & 15.32 \\
\hline Bacteroidetes & 13.07 & 0.95 & 0.48 & 6.13 & 0.99 & 0.51 & 29.75 & 2.13 & 2.58 & 7.12 & 0.44 & 0.53 & 4.98 & 1.38 & 1.36 & 30.87 & 2.42 & 2.71 \\
\hline Candidate_division_JS1 & & & 0.01 & 0.70 & 0.10 & 1.02 & 0.36 & 0.09 & 0.29 & & & & & & & 2.44 & 1.50 & 2.42 \\
\hline Chlorobi & 2.93 & 14.12 & 3.46 & 3.50 & 4.41 & 8.73 & 0.19 & 4.75 & 2.55 & 9.26 & 5.36 & 4.32 & 4.73 & 5.29 & 4.92 & 0.09 & 2.85 & 1.82 \\
\hline Chloroflexi & 12.90 & 11.15 & 7.31 & 12.78 & 4.12 & 9.36 & 6.62 & 11.39 & 12.77 & 12.59 & 6.80 & 7.46 & 9.37 & 10.10 & 10.03 & 2.07 & 4.80 & 8.34 \\
\hline Deinococcus-Thermus & & 0.03 & 2.31 & 8.75 & 0.88 & 4.83 & 1.37 & 0.64 & 2.64 & & 0.54 & 7.55 & & 0.05 & 0.68 & 0.86 & 1.99 & 2.77 \\
\hline Firmicutes & 1.22 & 1.57 & 0.80 & 13.21 & 13.47 & 13.39 & 6.27 & 10.73 & 10.00 & 0.97 & 0.88 & 0.75 & 0.69 & 0.30 & 0.29 & 18.56 & 25.95 & 26.56 \\
\hline Gemmatimonadetes & 1.24 & 0.96 & 3.11 & 1.44 & 0.58 & 2.50 & 1.90 & 0.91 & 5.77 & 0.44 & 0.58 & 1.63 & 0.59 & 2.18 & 5.27 & * & 0.38 & 0.51 \\
\hline Nitrospirae & & & & 0.00 & & & 0.00 & & & 0.54 & 0.09 & 0.25 & 1.07 & 0.70 & 0.38 & * & & \\
\hline Planctomycetes & 4.54 & 7.68 & 3.74 & 4.19 & 2.95 & 1.73 & 2.62 & 5.97 & 4.26 & 1.47 & 1.74 & 0.62 & 2.57 & 3.39 & 0.71 & 0.45 & 1.44 & 3.08 \\
\hline Proteobacteria & 32.47 & 31.68 & 49.15 & 22.04 & 39.40 & 36.43 & 25.07 & 31.94 & 37.40 & 45.24 & 38.28 & 53.77 & 46.71 & 27.61 & 55.55 & 10.30 & 28.14 & 23.86 \\
\hline SHA-109 & & 0.27 & & & 0.01 & & 0.01 & & 0.01 & $*$ & 0.37 & 0.08 & & 0.34 & 0.06 & & & 1.49 \\
\hline Spirochaetae & * & & * & * & & * & 0.00 & * & & * & & & * & & 0.01 & 2.95 & 0.01 & \\
\hline Tenericutes & * & * & ${ }^{*}$ & & * & * & 0.04 & * & 0.01 & * & * & & & * & & 1.36 & 0.01 & * \\
\hline Others & 16.18 & 5.69 & 7.78 & 15.45 & 5.05 & 6.96 & 20.56 & 7.33 & 11.88 & 18.27 & 4.32 & 6.04 & 23.97 & 9.45 & 8.53 & 22.65 & 5.69 & 8.16 \\
\hline
\end{tabular}

Relative abundance $<0.01 \%$

Table 4

Identification of the main operational taxonomic units (OTUs) presented in Fig. 6 and source of their closest relative sequences.

\begin{tabular}{|c|c|c|c|c|c|}
\hline OTU & Identification (RDP-II) & Closest relative sequence (BLAST) & $\begin{array}{l}\text { Accession } \\
\text { number }\end{array}$ & $\begin{array}{l}\text { Similarity } \\
(\%)\end{array}$ & Source of the closest relative sequence \\
\hline 1 & Bacteria; Armatimonadetes; Armatimonadetes_grp5 & Clone AMX001BXFT7 & LC094877 & 99 & Sludge from an anammox UASB reactor \\
\hline 2 & Bacteria; Proteobacteria; Betaproteobacteria; Rhodocyclales; Rhodocyclaceae; Azoarcus & Azoarcus sp. PA01 16S rRNA & KT784536 & 99 & Unknown \\
\hline 3 & Bacteria; Proteobacteria; Betaproteobacteria; Burkholderiales; Burkholderiaceae & Clone AMX001BA4AW & LC094801 & 99 & Sludge from an anammox UASB reactor \\
\hline 4 & Bacteria; Bacteroidetes; Sphingobacteriia; Sphingobacteriales; Saprospiraceae & Clone E7-201 bp & KJ993903 & 99 & Earthworm gut \\
\hline 5 & Bacteria; Firmicutes; Clostridia; Clostridiales; Clostridiaceae_1; Clostridium_sensu_stricto_1 & DGGE gel band RB2-79 & KT835589 & 99 & $\begin{array}{l}\text { SBRs performing N-removal via nitrite treating } \\
\text { swine wastewater }\end{array}$ \\
\hline 10 & $\begin{array}{l}\text { Bacteria; Gemmatimonadetes; Gemmatimonadetes; Gemmatimonadales; } \\
\text { Gemmatimonadaceae; Gemmatimonas }\end{array}$ & Clone SEAB1AA061 & KC432372 & 99 & Wetland \\
\hline 11 & Bacteria; Proteobacteria; Betaproteobacteria; Rhodocyclales; Rhodocyclaceae & Clone L1A.6H12 & AY989011 & 97 & Soil \\
\hline 12 & Bacteria; Chlorobi; Ignavibacteria; Ignavibacteriales & Clone AMX001CIOAL & LC094916 & 99 & Sludge from an anammox UASB reactor \\
\hline 18 & Bacteria; Proteobacteria; Gammaproteobacteria; unclassified & Clone MISEQ01_89 & КР356069 & 99 & Biofilm in a bioelectrochemical system \\
\hline 19 & Bacteria; Bacteroidetes; unclassified & CloneAMX001B2NAV & LC094861 & 99 & Sludge from an anammox UASB reactor \\
\hline 21 & Bacteria; Chloroflexi; Anaerolineae; Anaerolineales; Anaerolineaceae & Clone HAD103 & HG380607 & 99 & $\begin{array}{l}\text { Simultaneous autotrophic and heterotrophic } \\
\text { denitrification process }\end{array}$ \\
\hline 36 & $\begin{array}{l}\text { Bacteria; Planctomycetes; Planctomycetacia; Brocadiales; Brocadiaceae; } \\
\text { Candidatus_Brocadia }\end{array}$ & $\begin{array}{l}\text { Candidatus Brocadia sinica Clone } \\
\text { MBR_day_30 }\end{array}$ & КT023580 & 99 & Anammox biomass in a membrane bioreactor \\
\hline 63 & Bacteria; Bacteroidetes; unclassified & Clone B252 & KJ730164 & 99 & Biogas digester sediment \\
\hline 74 & Bacteria; Chloroflexi; Anaerolineae; Anaerolineales; Anaerolineaceae & Clone: AMX001C54CS & LC094933 & 99 & Sludge from an anammox UASB reactor \\
\hline 128 & Bacteria; Acidobacteria; unclassified & DGGE band ANAMMOX11 & AM900571 & 99 & Anammox batch culture \\
\hline
\end{tabular}




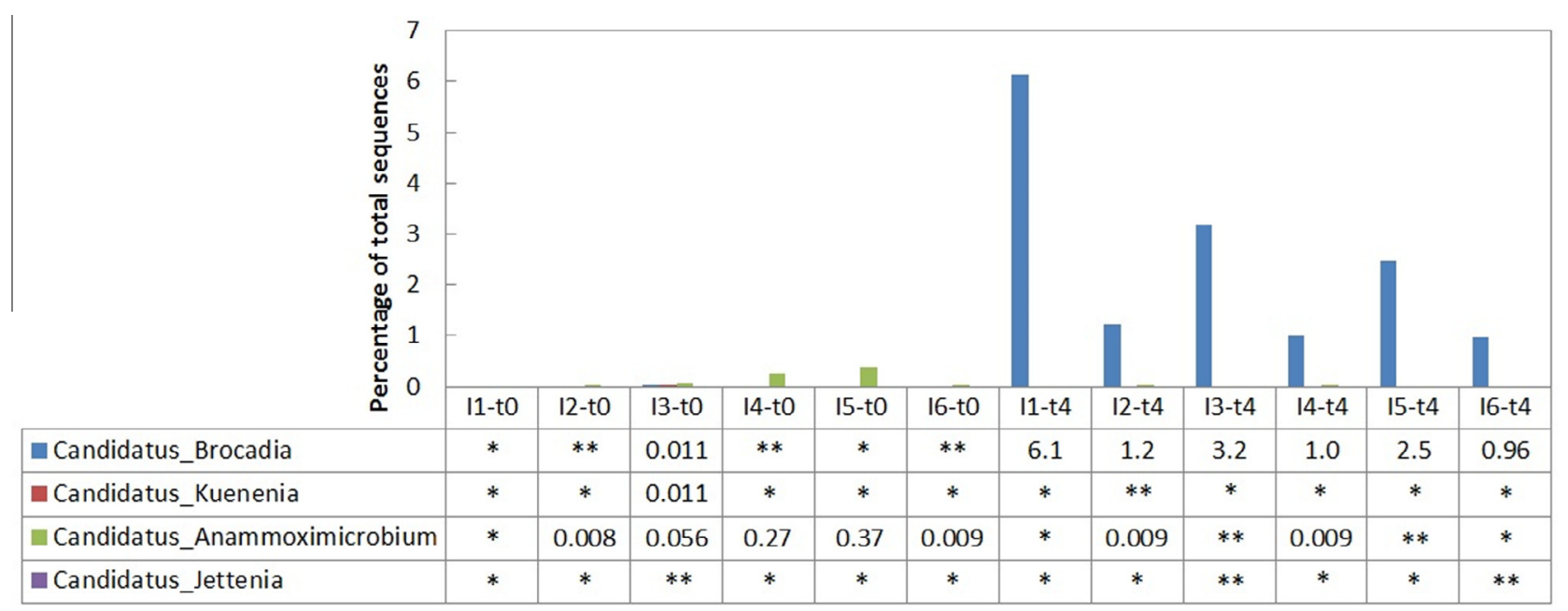

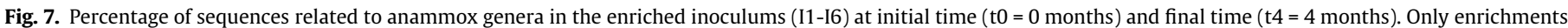

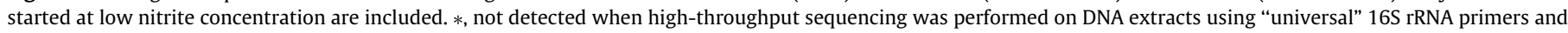

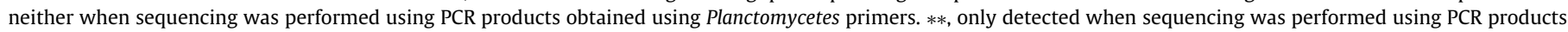
obtained using Planctomycetes primers, so relative abundance cannot be quantified $(<0.009 \%)$.

Planctomycetes primers, which allowed lowering the detection threshold but preclude their relative quantification (Fig. 7). Before enrichment, higher relative abundances were measured for Ca. Anammoximicrobium in I4 and I5 (lagoon WWTP), with $0.27 \%$ and $0.37 \%$, respectively, of the total sequences. In fact, this anammox genus (which was recently described) may grow optimally at temperatures around $20^{\circ} \mathrm{C}$ [7]. On the other hand, the genus Ca. Brocadia (maximum initial relative abundance of $0.011 \%$ for $\mathrm{I} 3$ ) became dominant at the end of the enrichment period regardless of the inoculum considered, with relative abundances ranging from 1.0 to $6.1 \%$ of the total sequences. Thus, similarly to Costa et al. [34], the obtained results indicated that while the type of inoculum and the culture conditions are both key determinants of the global microbial composition of the enriched biomass, the operational conditions alone determined the selection of the anammox species. The niche differentiation between Ca. Brocadia and other anammox genera often dominant in enrichments performed at lab-scale such as Ca. Kuenenia is still not clear. According to several studies [36,67-69], the genus Ca. Brocadia would presumably be an r-strategist (i.e., relatively high growth rate and low substrate affinity), while the genus Ca. Kuenenia could be a K-strategist (i.e., relatively low growth rate and high substrate affinity). In this study, the feeding of the enrichments was based on the intermittent supply of substrates which would favor the proliferation of an r-strategist population.

Overall, our findings showed that anammox bacteria were ubiquitous in all the inoculums collected from different waste/water treatment environments which made feasible their eventual enrichment in batch under controlled conditions. However, such enrichment was only achieved when the process was started at low $\mathrm{NO}_{2}^{-}$concentration ( $\leqslant 25 \mathrm{mg} \mathrm{NO}_{2}^{-}-\mathrm{N} / \mathrm{L}$ ) evidencing the importance of carefully controlling the conditions applied (i.e., substrate concentration). The procedure used prompted the enrichment of the anammox genus Ca. Brocadia regardless of the inoculum source. A higher initial anammox biomass concentration (measured as hzo gene copy number) did not necessarily imply a faster process start-up. Thus, other physicochemical and ecological characteristics of the inoculum affected the evolution of the enrichment since they determined issues such as the competition for substrate, coexisting microbial groups, dominant anammox species, and associated relative abundances at the beginning of the process.

\section{Conclusions}

The effect of $\mathrm{NO}_{2}^{-}$supply during the batch enrichment (4 months) of anammox sludge was investigated using six different biomass sources. Concerning the mineral medium used as feeding solution, two different $\mathrm{NO}_{2}^{-}$supply strategies were applied; i.e., (i) initially low concentration at $25 \mathrm{mg} \mathrm{NO}-\mathrm{N} / \mathrm{L}$ and progressive increase to $150 \mathrm{mg} \mathrm{NO}_{2}^{-}-\mathrm{N} / \mathrm{L}$, and (ii) constant high concentration at $150 \mathrm{mg} \mathrm{NO}--\mathrm{N} / \mathrm{L}$.

- All tested inoculums developed anammox activity only when the enrichment was started at low $\mathrm{NO}_{2}^{-}$concentration. In such case, the final specific $\mathrm{NH}_{4}^{+}$conversion rate was measured within the range from 21 to $118 \mathrm{mg} \mathrm{NH}_{4}^{+}-\mathrm{N} / \mathrm{g} \mathrm{VS} / \mathrm{d}$.

- Abundance of the $h z o$ functional gene showed positive correlation with the anammox activity finally reported.

- The biomass source, a conditioning pretreatment, and the cultivation conditions applied were determinant factors of the final microbial composition of the enrichments despite a clear convergence at the end of the experimental period. However, the cultivation conditions alone determined the selection of anammox species belonging to the genus Ca. Brocadia.

\section{Acknowledgements}

Authors thank Rennes Métropole for funding this research through the assignment of the allocation d'installation scientifique ref. 14C0509. Sophie Le Roux and Chrystelle Bureau are acknowledged for their technical assistance during microbial analyses whereas Olivier Chapleur is acknowledged for his help in processing DNA sequencing data.

\section{References}

[1] M. Strous, J.J. Heijnen, J.G. Kuenen, M.S.M. Jetten, The sequencing batch reactor as a powerful tool for the study of slowly growing anaerobic ammoniumoxidizing microorganisms, Appl. Microbiol. Biotechnol. 50 (1998) 589-596.

[2] M. Strous, E. Pelletier, S. Mangenot, T. Rattei, A. Lehner, M.W. Taylor, M. Horn, H. Daims, D. Bartol-Mavel, P. Wincker, V. Barbe, N. Fonknechten, D. Vallenet, B. Segurens, C. Schenowitz-Truong, C. Médigue, A. Collingro, B. Snel, B.E. Dutilh, H.J.M. Op den Camp, C. van der Drift, I. Cirpus, K.T. van de Pas-Schoonen, H.R. Harhangi, L. van Niftrik, M. Schmid, J. Keltjens, J. van de Vossenberg, B. Kartal, H. Meier, D. Frishman, M.A. Huynen, H.-W. Mewes, J. Weissenbach, M.S.M. 
Jetten, M. Wagner, D. Le Paslier, Deciphering the evolution and metabolism of an anammox bacterium from a community genome, Nature 440 (2006) 790 794.

[3] A. Mulder, A.A. van de Graaf, L.A. Robertson, J.G. Kuenen, Anaerobic ammonium oxidation discovered in a denitrifying fluidized bed reactor, FEMS Microbiol. Ecol. 16 (1995) 177-184.

[4] K.R. Arrigo, Marine microorganisms and global nutrient cycles, Nature 437 (2005) 349-355.

[5] B. Kartal, J.G. Kuenen, M.C.M. van Loosdrecht, Sewage treatment with Anammox, Science 328 (2010) 702-703.

[6] M.S.M. Jetten, L. van Niftrik, M. Strous, B. Kartal, J.T. Keltjens, H.J.M. Op den Camp, Biochemistry and molecular biology of anammox bacteria, Crit. Rev. Biochem. Mol. Biol. 44 (2009) 65-84.

[7] S.V. Khramenkov, M.N. Kozlov, M.V. Kevbrina, A.G. Dorofeev, E.A. Kazakova, V. A. Grachev, B.B. Kuznetsov, D.Y. Polyakov, Y.A. Nikolaev, A novel bacterium carrying out anaerobic ammonium oxidation in a reactor for biological treatment of the filtrate of wastewater fermented sludge, Microbiology 82 (2013) 628-636.

[8] T. Lotti, R. Kleerebezem, J.M. Abelleira-Pereira, B. Abbas, M.C.M. van Loosdrecht, Faster through training: the anammox case, Water Res. 81 (2015) 261-268.

[9] H. Bae, K.-S. Park, Y.-C. Chung, J.-Y. Jung, Distribution of anammox bacteria in domestic WWTPS and their enrichments evaluated by real-time quantitative PCR, Process Biochem. 45 (2010) 323-334.

[10] M. Waki, T. Yasuda, K. Suzuki, T. Sakai, N. Suzuki, R. Suzuki, K. Matsuba, H. Yokoyama, A. Ogino, Y. Tanaka, S. Ueda, M. Takeuchi, T. Yamagishi, Y. Suwa, Rate determination and distribution of anammox activity in activated sludge treating swine wastewater, Bioresour. Technol. 101 (2010) 2685-2690.

[11] B. Thamdrup, T. Dalsgaard, Production of $\mathrm{N}_{2}$ through anaerobic ammonium oxidation coupled to nitrate reduction in marine sediments, Appl. Environ. Microbiol. 68 (2002) 1312-1318.

[12] M. Li, Y. Hong, M.G. Klotz, J.-D. Gu, A comparison of primer sets for detecting 16S rRNA and hydrazine oxidoreductase genes of anaerobic ammoniumoxidizing bacteria in marine sediments, Appl. Microbiol. Biotechnol. 86 (2010) $781-790$.

[13] I. Yoshinaga, T. Amano, T. Yamagishi, K. Okada, S. Ueda, Y. Sako, Y. Suwa, Distribution and diversity of anaerobic ammonium oxidation (anammox) bacteria in the sediment of a eutrophic freshwater lake, Lake Kitaura, Japan, Microbes Environ. 26 (2011) 189-197.

[14] A. Long, J. Heitman, C. Tobias, R. Philips, B. Song, Co-occurring anammox, denitrification, and codenitrification in agricultural soils, Appl. Environ. Microbiol. 79 (2013) 168-176.

[15] H. Bae, Y.-C. Chung, J.-Y. Jung, Microbial community structure and occurrence of diverse autotrophic ammonium oxidizing microorganisms in the anammox process, Water Sci. Technol. 61 (2010) 2723-2732.

[16] S. Qiao, Y. Kawakubo, Y. Cheng, T. Nishiyama, T. Fujii, K. Furukawa, Identification of bacteria coexisting with anammox bacteria in an upflow column type reactor, Biodegradation 20 (2009) 117-124.

[17] M. Ibrahim, N. Yusof, M.Z.M. Yusoff, M.A. Hassan, Enrichment of anaerobic ammonium oxidation (anammox) bacteria for short start-up of the anammox process: a review, Desalin. Water Treat. 57 (2016) 13958-13978.

[18] K. Egli, F. Bosshard, C. Werlen, P. Lais, H. Siegrist, A.J.B. Zehnder, J.R. van der Meer, Microbial composition and structure of a rotating biological contactor biofilm treating ammonium-rich wastewater without organic carbon, Microb. Ecol. 45 (2003) 419-432.

[19] T. Fujii, H. Sugino, J.D. Rouse, K. Furukawa, Characterization of the microbial community in an anaerobic ammonium-oxidizing biofilm cultured on a nonwoven biomass carrier, J. Biosci. Bioeng. 94 (2002) 412-418.

[20] T. Wang, H. Zhang, F. Yang, S. Liu, Z. Fu, H. Chen, Start-up of the Anammox process from the conventional activated sludge in a membrane bioreactor Bioresour. Technol. 100 (2009) 2501-2506.

[21] S.K. Toh, R.I. Webb, N.J. Ashbolt, Enrichment of autotrophic anaerobic ammonium-oxidizing consortia from various wastewaters, Microb. Ecol. 43 (2002) 154-167.

[22] A. Sànchez-Melsió, J. Cáliz, M.D. Balaguer, J. Colprim, X. Vila, Development of batch-culture enrichment coupled to molecular detection for screening of natural and man-made environments in search of anammox bacteria for N-removal bioreactors systems, Chemosphere 75 (2009) 169-179.

[23] W. Sun, Q. Banihani, R. Sierra-Alvarez, J.A. Field, Stoichiometric and molecular evidence for the enrichment of anaerobic ammonium oxidizing bacteria from wastewater treatment plant sludge samples, Chemosphere 84 (2011) $1262-1269$.

[24] Y. Tao, D.-W. Gao, H.-Y. Wang, M. de Kreuk, N.-Q. Ren, Ecological characteristics of seeding sludge triggering a prompt start-up of anammox, Bioresour. Technol. 133 (2013) 475-481.

[25] C. Fux, V. Marchesi, I. Brunner, H. Siegrist, Anaerobic ammonium oxidation of ammonium-rich waste streams in fixed-bed reactors, Water Sci. Technol. 49 $(11-12)(2004) 77-82$.

[26] R.-C. Jin, G.-F. Yang, J.-J. Yu, P. Zheng, The inhibition of the Anammox process: a review, Chem. Eng. J. 197 (2012) 67-79.

[27] Y. Tao, D.-W. Gao, Impact of ecological factors on anaerobic ammoniaoxidizing bacteria enrichments, Environ. Eng. Sci. 29 (2012) 479-485.

[28] J.M. Carvajal-Arroyo, W. Sun, R. Sierra-Alvarez, J.A. Field, Inhibition of anaerobic ammonium oxidizing (anammox) enrichment cultures by substrates, metabolites and common wastewater constituents, Chemosphere 91 (2013) 22-27.
[29] I. Tsushima, T. Kindaichi, S. Okabe, Quantification of anaerobic ammoniumoxidizing bacteria in enrichment cultures by real-time PCR, Water Res. 41 (2008) 785-794.

[30] C. Hao, H. Wang, Q. Liu, X. Li, Quantification of anaerobic ammonium-oxidizing bacteria in enrichment cultures by quantitative competitive PCR, J. Environ. Sci. 21 (2009) 1557-1561.

[31] B.-L. Hu, P. Zheng, C.-J. Tang, J.-W. Chen, E. van der Biezen, L. Zhang, B.-J. Ni, M. S.M. Jetten, J. Yan, H.-Q. Yu, B. Kartal, Identification and quantification of anammox bacteria in eight nitrogen removal reactors, Water Res. 44 (2010) 5014-5020.

[32] H. Park, A. Rosenthal, K. Ramalingam, J. Fillos, K. Chandran, Linking community profiles, gene expression and N-removal in anammox bioreactors treating municipal anaerobic digestion reject water, Environ. Sci. Technol. 44 (2010) 6110-6116.

[33] Z. Hu, D.R. Speth, K.-J. Francoijs, Z.-X. Quan, M.S.M. Jetten, Metagenome analysis of a complex community reveals the metabolic blueprint of anammox bacterium "Candidatus Jettenia asiatica”, Front. Microbiol. 3 (2012) 366.

[34] M.C.M.S. Costa, L. Carvalho, C.D. Leal, M.F. Dias, K.L. Martins, G.B. Garcia, I.D. Mancuelo, T. Hipólito, E.F.A. MacConell, D. Okada, C. Etchebehere, C.A.L. Chernicharo, J.C. Araujo, Impact of inocula and operating conditions on the microbial community structure of two anammox reactors, Environ. Technol. 35 (2014) 1811-1822.

[35] A. Gonzalez-Martinez, F. Osorio, J.A. Morillo, A. Rodriguez-Sanchez, J. Gonzalez-Lopez, B.A. Abbas, M.C.M. van Loosdrecht, Comparison of bacterial diversity in full scale anammox bioreactors operated under different conditions, Biotechnol. Progr. 31 (2015) 1464-1472.

[36] E. Isanta, T. Bezerra, I. Fernández, M.E. Suárez-Ojeda, J. Pérez, J. Carrera, Microbial community shifts on an anammox reactor after a temperature shock using 454-pyrosequencing analysis, Bioresour. Technol. 181 (2015) 207-213.

[37] S. Lackner, E.M. Gilbert, S.E. Vlaeminck, A. Joss, H. Horn, M.C.M. van Loosdrecht, Full-scale partial nitritation/anammox experiences - an application survey, Water Res. 55 (2014) 292-303.

[38] G. Xu, Y. Zhou, Q. Yang, Z.M.-P. Lee, J. Gu, W. Lay, Y. Cao, Y. Liu, The challenges of mainstream deammonification process for municipal used water treatment, Appl. Microbiol. Biotechnol. 99 (2015) 2485-2490.

[39] S.W.H. Van Hulle, H.J.P. Vandeweyer, B.D. Meesschaert, P.A. Vanrolleghem, P. Dejans, A. Dumoulin, Engineering aspects and practical application of autotrophic nitrogen removal from nitrogen rich streams, Chem. Eng. J. 162 (2010) 1-20.

[40] A. Magrí, F. Béline, P. Dabert, Feasibility and interest of the anammox process as treatment alternative for anaerobic digester supernatants in manure processing - an overview, J. Environ. Manage. 131 (2013) 170-184.

[41] B. Wett, S. Murthy, I. Takács, M. Hell, G. Bowden, A. Deur, M. O’Shaughnessy, Key parameters for control of DEMON deammonification process, Water Pract. 1 (2007) 1-11.

[42] E. Bettazzi, S. Caffaz, C. Vannini, C. Lubello, Nitrite inhibition and intermediates effects on Anammox bacteria: a batch-scale experimental study, Process Biochem. 45 (2010) 573-580.

[43] A. Dapena-Mora, I. Fernández, J.L. Campos, A. Mosquera-Corral, R. Méndez, M. S.M. Jetten, Evaluation of activity and inhibition effects on Anammox process by batch tests based on the nitrogen gas production, Enzyme Microb. Technol. 40 (2007) 859-865.

[44] Y. Kimura, K. Isaka, F. Kazama, T. Sumino, Effects of nitrite inhibition on anaerobic ammonium oxidation, Appl. Microbiol. Biotechnol. 86 (2010) 359365.

[45] A. Magrí, M.B. Vanotti, A.A. Szögi, Anammox sludge immobilized in polyvinyl alcohol (PVA) cryogel carriers, Bioresour. Technol. 114 (2012) 231-240.

[46] H. López, S. Puig, R. Ganigué, M. Ruscalleda, M.D. Balaguer, J. Colprim, Start-up and enrichment of a granular anammox SBR to treat high nitrogen load wastewaters, J. Chem. Technol. Biotechnol. 83 (2008) 233-241.

[47] A. Magrí, M.B. Vanotti, A.A. Szögi, K.B. Cantrell, Partial nitritation of swine wastewater in view of its coupling with the anammox process, J. Environ. Qual. 41 (2012) 1989-2000.

[48] Z. Hu, T. Lotti, M. de Kreuk, R. Kleerebezem, M. van Loosdrecht, J. Kruit, M.S.M. Jetten, B. Kartal, Nitrogen removal by a nitritation-anammox bioreactor at low temperature, Appl. Environ. Microbiol. 79 (2013) 2807-2812.

[49] M.J. Ferris, G. Muyzer, D.M. Ward, Denaturing gradient gel electrophoresis profiles of $16 \mathrm{~S}$ rRNA-defined populations inhabiting a hot spring microbial mat community, Appl. Environ. Microbiol. 62 (1996) 340-346.

[50] M.C. Schmid, A.B. Hooper, M.G. Klotz, D. Woebken, P. Lam, M.M.M. Kuypers, A. Pommerening-Roeser, H.J.M. op den Camp, M.S.M. Jetten, Environmental detection of octahaem cytochrome $c$ hydroxylamine/hydrazine oxidoreductase genes of aerobic and anaerobic ammonium-oxidizing bacteria, Environ. Microbiol. 10 (2008) 3140-3149.

[51] Y. Zeng, A. De Guardia, C. Ziebal, FJ. De Macedo, P. Dabert, Nitrification and microbiological evolution during aerobic treatment of municipal solid wastes, Bioresour. Technol. 110 (2012) 144-152.

[52] S. Poirier, E.D.-L. Quéméner, C. Madigou, T. Bouchez, O. Chapleur, Anaerobic digestion of biowaste under extreme ammonia concentration: identification of key microbial phylotypes, Bioresour. Technol. 207 (2016) 92-101.

[53] Y. Wang, P.-Y. Qian, Conservative fragments in bacterial 16S rRNA genes and primer design for $16 \mathrm{~S}$ ribosomal DNA amplicons in metagenomic studies, PLoS One 4 (2009) e7401.

[54] J.G. Caporaso, J. Kuczynski, J. Stombaugh, K. Bittinger, F.D. Bushman, E.K. Costello, N. Fierer, A. Gonzalez Pena, J.K. Goodrich, J.I. Gordon, G.A. Huttley, S.T. Kelley, D. Knights, J.E. Koenig, R.E. Ley, C.A. Lozupone, D. McDonald, B.D. 
Muegge, M. Pirrung, J. Reeder, J.R. Sevinsky, P.J. Turnbaugh, W.A. Walters, J. Widmann, T. Yatsunenko, J. Zaneveld, R. Knight, QIIME allows analysis of highthroughput community sequencing data, Nat. Methods 7 (2010) 335-336.

[55] R.C. Edgar, UPARSE: highly accurate OTU sequences from microbial amplicon reads, Nat. Methods 10 (2013) 996-998.

[56] P.D. Schloss, S.L. Westcott, T. Ryabin, J.R. Hall, M. Hartmann, E.B. Hollister, R.A. Lesniewski, B.B. Oakley, D.H. Parks, C.J. Robinson, J.W. Sahl, B. Stres, G.G. Thallinger, D.J. Van Horn, C.F. Weber, Introducing mothur: open-source, platform-independent, community-supported software for describing and comparing microbial communities, Appl. Environ. Microbiol. 75 (2009) $7537-$ 7541.

[57] C. Quast, E. Pruesse, P. Yilmaz, J. Gerken, T. Schweer, P. Yarza, J. Peplies, F.O. Glöckner, The SILVA ribosomal RNA gene database project: improved data processing and web-based tools, Nucleic Acids Res. 41 (2013) D590-D596.

[58] W.N. Venables, D.M. Smith, the R Core Team, An Introduction to R, Notes on R: A Programming Environment for Data Analysis and Graphics, version 3.2.4, 2016. URL: https://cran.r-project.org/doc/manuals/r-release/R-intro.pdf (last accessed: March 28th, 2016).

[59] J. Oksanen, F.G. Blanchet, R. Kindt, P. Legendre, P.R. Minchin, R. B. O'Hara, G.L. Simpson, P. Solymos, M.H.H. Stevens, H. Wagner, Package "vegan", Community Ecology Package, version 2.3-4, 2016. URL: https://cran.r-project.org/ web/packages/vegan/vegan.pdf (last accessed: March 28th, 2016).

[60] J. Oksanen, Vegan: Ecological Diversity, 2016. URL: https://cran.r-project.org/ web/packages/vegan/vignettes/diversity-vegan.pdf (last accessed: March 28th, 2016).

[61] A.E. Magurran, Measuring Biological Diversity, Blackwell Science Ltd, UK, 2004.
[62] M. Hu, X. Wang, X. Wen, Y. Xia, Microbial community structures in differen wastewater treatment plants as revealed by 454-pyrosequencing analysis, Bioresour. Technol. 117 (2012) 72-79.

[63] D. Rivière, V. Desvignes, E. Pelletier, S. Chaussonnerie, S. Guermazi, J. Weissenbach, T. Li, P. Camacho, A. Sghir, Towards the definition of a core of microorganisms involved in anaerobic digestion sludge, ISME J. 3 (2009) 700714.

[64] N. Fierer, M.A. Bradford, R.B. Jackson, Toward an ecological classification of soil bacteria, Ecology 88 (2007) 1354-1364.

[65] T. Kindaichi, S. Yuri, N. Ozaki, A. Ohashi, Ecophysiological role and function of uncultured Chloroflexi in an anammox reactor, Water Sci. Technol. 66 (2012 2556-2561.

[66] H. Tamaki, Y. Tanaka, H. Matsuzawa, M. Muramatsu, X.-Y. Meng, S. Hanada, K. Mori, Y. Kamagata, Armatimonas rosea gen. nov., sp. nov., of a novel bacterial phylum, Armatimonadetes phyl. nov., formally called the candidate phylum OP10, Int. J. Syst. Evol. Microbiol. 61 (2011) 1442-1447.

[67] W.R.L. van der Star, A.I. Miclea, U.G.J.M. van Dongen, G. Muyzer, C. Picioreanu, M.C.M. van Loosdrecht, The membrane bioreactor: a novel tool to grow anammox bacteria as free cells, Biotechnol. Bioeng. 101 (2008) 286-294.

[68] M. Oshiki, M. Shimokawa, N. Fujii, H. Satoh, S. Okabe, Physiological characteristics of the anaerobic ammonium-oxidizing bacterium 'Candidatus Brocadia sinica', Microbiology 157 (2011) 1706-1713.

[69] D. Puyol, J.M. Carvajal-Arroyo, B. Garcia, R. Sierra-Alvarez, J.A. Field, Kinetic characterization of Brocadia spp.-dominated anammox cultures, Bioresour. Technol. 139 (2013) 94-100. 